\title{
Evolution of Risk and Political Regimes
}

\section{Citation}

Petrova, Maria, and Robert H. Bates. 2012. "Evolution of Risk and Political Regimes." Economics \& Politics 24 (2) (July): 200-225.

\section{Published Version}

doi:10.1111/j.1468-0343.2012.0398.x

\section{Permanent link}

http://nrs.harvard.edu/urn-3:HUL.InstRepos:12211560

\section{Terms of Use}

This article was downloaded from Harvard University's DASH repository, and is made available under the terms and conditions applicable to Open Access Policy Articles, as set forth at http:// nrs.harvard.edu/urn-3:HUL.InstRepos:dash.current.terms-of-use\#OAP

\section{Share Your Story}

The Harvard community has made this article openly available.

Please share how this access benefits you. Submit a story.

Accessibility 


\title{
Evolution of Risk and Political Regimes*
}

\author{
Maria Petrova ${ }^{\dagger}$ and Robert Bates ${ }^{\ddagger}$
}

July 2011

\begin{abstract}
The risk of political predation impedes the achievement of economic prosperity. In this paper, we analyze how the risk of predation evolves in different political regimes. Formally, we look at the interaction between a government and citizens in which, in each period, the government has an option to predate. Citizens prefer governments that are competent and non-predatory and strive to replace ones that are not. Regimes differ in the degree to which citizens can succeed in doing so. In pure democracies, citizens can displace incumbent governments; in pure autocracies, they cannot; and in intermediate cases, they can do so in probability. After economic downturns, the posterior probability that the government is competent and benevolent declines. According to the model, in intermediate regimes, but not in others, governments can separate by type. One implication, then, is that these regimes are politically and economically more volatile, with higher levels of variation in assessments of political risk and in economic performance. Another is that in such regimes, political leadership can make an economic difference. Empirically, we test our argument by measuring the impact of economic downturns on the perceived risk of political expropriation in different regime types, using as instruments the incidence of natural disasters and unexpected terms of trade shocks.
\end{abstract}

\footnotetext{
*An earlier version of this paper was circulated by the name "Political Expectations and Economic Performance." We are grateful to Sergei Guriev, Alison Post, Ken Shepsle, Katia Zhurvaskaya, and seminar participants at Harvard University, New Economic School, Midwest Political Science Association meeting, American Political Science Association meeting, and ISNIE meeting for helpful discussions. We thank Nikolay Dudchenko, Julie Faller, Jeannine Hollaus, Grigory Naukhatsky, and Gleb Romanyuk for excellent research assistance.

${ }^{\dagger}$ New Economic School. UBS Assistant Professor of Economics. Office 905 Nakhimovsky pr. 47 Moscow 117418 Russia. E-mail: mpetrova@nes.ru. Corresponding author.

${ }^{\ddagger}$ Harvard University. Eaton Professor of the Science of Government. Department of Government, Harvard University, 1737 Cambridge St., Cambridge, MA 02138. robert_bates@harvard.edu.
} 


\section{Introduction}

The "Third Wave" refers to the process of democratization that began with the transition from authoritarian rule in Iberia, culminated in the fall of the Soviet Union, and inspired political reform in late-century Africa (Huntington 1991). As noted by Geddes (2003), what resulted was not the creation of democracies; it was the creation of intermediate or mixed regimes. As shown in Figure 1, in the mid-1970's, these regimes prevailed in less than $4 \%$ of the world's states; by the year 2000 , they prevailed in more than one quarter.

The behavior of intermediate regimes appears erratic. Focusing on political outcomes, Goldstone, Marshall et al. (2003), Hegre (2004) and Gates, Hegre et al. (2001) demonstrate that they are less stable politically than are full democracies or autocracies (see also Fearon and Laitin, 2003). Kenyon and Naoi (2010) find that policy uncertainty is also greater in such regimes. And Epstein et al. (2006) conclude that while, pace (Przeworski, Alvarez et al. 2000), a variety of modernization variables, including per capita income, systematically relate to the transition from authoritarian to democratic regimes, none bears a systematic relationship to transitions into or out of the category of intermediate regimes. Epstein et al. (2006) therefore appear to be speaking for the generation of scholars who first addressed this new category of political system when they write: "These are 'fragile' democracies, or perhaps 'unconsolidated democracies.' Whatever one wishes to call them, they emerge .. as [m]ore volatile than either straight autocracies or democracies. Their [behavior] seems at the moment to be largely unpredictable" (p. 24).

Common sense and economic reasoning (North and Weingast 1989; Acemoglu et al. 2003) posit a relationship between political restraint and economic performance. When those who possess capital face the prospect of confiscation, they will refrain from investing; and entrepreneurs will be more willing to innovate when they stand to reap the fruits of their labor. On the basis of such reasoning, scholars expected to find that democracies would achieve higher growth rates than did authoritarian regimes. However, they do not. As documented by Boix and Svolik (2008), Haber (2006), Haber et al. (2006) 
and Gelbach and Keefer (2008 2009), some authoritarian regimes appear to be able credibly to signal political restraint and to attract capital. As a result, their economic performance approximates that of democracies. ${ }^{1}$ As scholars have probed the structure of non-democratic regimes, they have noted the existence of institutional checks, such as legislatures, opposition parties, and elections (Gandhi 2008, Gandhi and Przeworski 2006 and 2007, Cox 2009, Collier and Levitsky 1997, Levitsky and Way 2002, Magaloni 2006 and others, such as Boix and Svolik 2008 Pop-Eliches and Robinson 2009, Henisz 2000, and Henisz and Williamson 1999). Given a relationship between political restraint and economic performance, and given the institutional heterogeneity of autocracies, it is therefore not surprising that the economies of some outperform those of the democracies . For, as noted by Besley and Kudamatsu (2008), while the mean rate of growth among autocracies may have been lower than that for democracies, "the distribution has fatter tails ...." (p. 453, see also Przeworski et al. (2000)).

This article represents an attempt to model the major characteristics of intermediate regimes so as to account for their political behavior and their economic performance. While we are unable to test our model directly, we do exploit one of its basic implications: that under well-specified conditions, economic performance can be politically informative. In particular, the model implies that at intermediate levels of political restraint, assessments of political risk should vary with the state of the economy and therefore alter subsequent outcomes.

To test this implication, we use panel country data. In contrast to Ramey and Ramey (1995), who analyze the relationship between economic volatility and average growth rates, we focus on the relationship between economic and political volatility and the manner in which it varies among regimes. We use measures of country risk, such as "expropriation risk" (Knack and Keefer 1998) that offer proxy for the risk of predation. To identify the effect of economic downturns, we instrument them with an incidence

\footnotetext{
${ }^{1}$ See also the literature on weak institutions, e.g. Acemoglu et al. (2004), Padro i Miguel (2007), and Bueno de Mesquita et al. (2003), and on the political origins of economic instability, i.e. Acemoglu et al. (2003), Rodrik (2000), Cuberes and Jerzmanowski (2009).
} 
of natural disasters and unexpected terms-of-trade shocks. To deal with unobserved heterogeneity, we control for country fixed effects. To ensure that the exclusion restriction is satisfied, we take lags of all the controls, so that all the variables except instrumented shock are observed prior to disasters or shocks. To the extent that natural disasters in the future cannot affect control variables today, the exclusion restriction holds. As one can argue that unexpected terms of trade shocks could still be endogenous, we show that there are no overidentifying restrictions under the assumption that natural disasters are exogenous. In the end, we find that, indeed, the risk of predation increases after growth downturns, and that this effect is the strongest in intermediate regimes.

\section{Informal Argument}

The polity is populated by citizens and their government. The government derives utility from being in office and the benefits of political predation. ${ }^{2}$ The citizens derive utility from an outcome, $y$, which we interpret as economic growth. At the end of each period, citizens can seek to replace the government. They succeed with some probability, which depends on the nature of political institutions.

Governments differ in their type. Some are competent: even if they enjoy private benefits, they do not always harm their citizens and, upon occasion, deliver positive policy outcomes. Others are incompetent: they are incapable of doing good for their citizens in most instances, and, upon occasion, they do them harm.

The behavior of the rulers depends upon their type and the incentives generated by the power of the citizens, i.e. their ability to change their government. If the citizens can easily dismiss the government, as in a consolidated democracy, both competent and incompetent governments will choose to refrain from

\footnotetext{
${ }^{2}$ By predatory policies we mean the policies that may be profitable for the government but harmful for the the long run welfare of citizens. Expropriation can be blatant, as in the case of Zimbabwe, where the government seized the land of farmers, the assets of firms, and the foreign exchange deposited with banks. Or it can be more subtle, resulting from the manipulation of the interest and exchange rates or inflation.
} 
predation. If it is difficult for the citizens to do so, as in full autocracies, both competent and incompetent governments will adopt policies that maximize their per-period rents. The level of political constraint that makes a government indifferent between predation and restraint is higher for the competent government. Under intermediate level of constraints, then, competent governments will refrain from predation while incompetent governments may not. Therefore, in intermediate regimes governments with different values

"separate,"thus revealing their type and generating a dispersion in the levels of investment and growth rates.

As different types of governments behave differently only in intermediate regimes, there should therefore be a higher variation of risk within them than within full democracies or autocracies. Moreover, in such countries, under imperfect information, the risk of predation should respond more significantly to economic shocks, as people treat them as signals of the nature of their government. By our model, then, there should be a higher variation of both cross-sectional variation and time-series volatility in intermediate regimes than in full democracies or autocracies.

\section{The Model}

\section{The Government}

The government might be competent or incompetent. It can predate and consume rents, but also generates an outcome $y$ for the citizens. Hereafter we assume that such an outcome takes the form of economic growth, but other interpretations are possible.

The government receives utility $B$ from being in office, a rent $R$ if engaged in predation, and cares about future periods.

Treating the competence of the government, $\theta \in\left\{\theta_{H}, \theta_{L}\right\}$, and the incidence of predation, $x \in\{0,1\}$, as binary, we associate the likelihood of a positive outcome with its type and its decision to engage in predation: 


$$
\| \begin{gathered}
\operatorname{Pr}\left(y=1 \mid \theta=\theta_{H}, x=0\right)=1 \\
\operatorname{Pr}\left(y=1 \mid \theta=\theta_{H}, x=1\right)=p_{H} \\
\operatorname{Pr}\left(y=1 \mid \theta=\theta_{L}, x=0\right)=p_{L} \\
\operatorname{Pr}\left(y=1 \mid \theta=\theta_{L}, x=1\right)=0
\end{gathered}
$$

If not engaged in predation, the government's per-period utility is $B$; if so engaged, its per-period utility is $B+R$. A government cares about future rents and discounts the future with factor $\delta .^{3}$ After the government is dismissed, its per-period utility is 0 thereafter.

The utility of a competent government is $V_{t}=B+\delta \operatorname{Pr}\left(\right.$ stays $\left.\mid y_{t}=1\right) V_{t+1}$ if it does not predate and $V_{t}=B+R+\delta\left(p_{H} \operatorname{Pr}\left(\right.\right.$ stays $\left.\mid y_{t}=1\right) V_{t+1}+\left(1-p_{H}\right) \operatorname{Pr}\left(\right.$ stays $\left.\left.\mid y_{t}=0\right) V_{t+1}\right)$ if it engages in predation (where stays means remains in power). The comparable values for an incompetent government are $V_{t}=$ $B+\delta\left(p_{L} \operatorname{Pr}\left(\right.\right.$ stays $\left.\mid y_{t}=1\right) V_{t+1}+\left(1-p_{L}\right) \operatorname{Pr}\left(\right.$ stays $\left.\left.\mid y_{t}=0\right) V_{t+1}\right)$ and $V_{t}=B+R+\delta \operatorname{Pr}\left(\right.$ stays $\left.\mid y_{t}=0\right) V_{t+1}$, respectively. The ex-ante probability of a competent government is $\mu$.

\section{Citizenry}

The citizens receive utility from $y$. Their per-period utility function is $f(y)$. The discounted long-term utility of citizens is given by $U_{t}=f(y)+\delta U_{t+1}$ if citizens do not try to overthrow the current government and by $U_{t}=f(y)-c(\gamma)+\delta\left(\gamma U^{*}+(1-\gamma) U_{t+1}\right)$ if they do. Here $U^{*}$ is the expected utility from a new government drawn from the distribution of new governments, while $U_{t+1}$ is the expected utility from retaining the current government. The term $c(\gamma)$ represents the costs of attempting to overthrow the current government. The discount factor for the citizens is the same as for the government.

Citizens might try to replace the government if they are not satisfied with its performance. If they want to do so - as, for example, if they estimate the competence of an old government, $\widehat{\mu_{t}}$, to be substantially smaller than the estimated competence of a new one, $\mu,-$ they succeed with probability $\gamma$. The variable $\gamma$

\footnotetext{
${ }^{3}$ It is possible to extend the model to allow the government to spend some benefits from predation on repression in order to prevent being overthrown, as in Besley and Persson (2011). In order to keep the model as simple as possible., we do not do so.
} 
thus captures the level of constraint faced by a government when making decisions: it can be interpreted as the probability that citizens succeed should they seek to overturn the government. If performance of the economy is poor, the citizens may attempt to replace the current government. If they succeed, the next government is competent (i.e. $\theta_{H}$ ) with the same ex-ante probability $\mu$. As a result, in the model the likelihood of a ruler being replaced is exogenous conditional on citizen's willingness to overthrow the government, which is a dichotomous function of the gap in perceived competence.

\section{Risk of predation}

The risk of predation is the probability that the government is going to predate in any given time period. Formally, $r_{t}$ denotes $\operatorname{Pr}\left(x_{t}=1 \mid y_{t-1}, \widehat{\mu_{t}}\right)$, the probability of $x=1$ in period $t$, given the history of observed events.

\section{Timing}

For simplicity, we consider a 3-period model. The structure of the game is common knowledge; in the last period, both the government and the people realize that the game is about to end.

In each period, the timing is:

1. The current government decides whether or not to predate and chooses $x \in\{0,1\}$.

2. The outcome variable $y$ is realized, with probabilities which depend on the government's decision to predate and the government's competence, as described in (1).

3. Citizens observe the outcome variable $y$ and decide whether to challenge the government; they succeed in overturning it with probability $\gamma$.

4. All agents get their per-period payoffs. Risk variables for the next period are calculated.

5. If in stage 3 people succeeded in overthrowing the government, the new government is drawn from the distribution of potential governments. 


\subsection{Solution}

The game is solved by backward induction. First, we consider what happens at $t=3$, then we look at $t=2$ and solve the continuation game between the people and the government given citizens' beliefs. Finally, we assign the continuation payoffs to all nodes in which the continuation game could start and solve the game at $t=1$. The solution forms a Perfect Bayesian Equilibrium.

In period $t=3$ :

All types of government choose to predate. As there is no next period, citizens do not overthrow the government because of the positive costs $c(\gamma)$.

In period $t=2$ :

Citizens know that the government is going to predate in period 3. As they prefer to have a competent government, but face the costs if try to overthrow the current one, they replace the current government whenever their posterior probability that the government is competent is less than some constant $\mu^{*}(\gamma)$ which is strictly less than the prior probability that the next government will be competent and depends on $c(\gamma)$, i.e. if $\widehat{\operatorname{Pr}}\left(\theta_{H}\right)<\mu^{*}(\gamma)$.

In the beginning of the period, the government can anticipate the strategy that the citizens will choose. A government wants to extract rents but also to stay in power. At this point, the continuation value of staying in power is $V_{3}=B+R$ for both governments that are competent and those that are not. A competent government compares $B+\delta \operatorname{Pr}($ stays in office $\mid y=1)[B+R]$ with $B+$ $R+\delta\left(p_{H} \operatorname{Pr}(\right.$ stays $\mid y=1)[B+R]+\left(1-p_{H}\right) \operatorname{Pr}($ stays $\left.\mid y=0)[B+R]\right)$. An incompetent government compares $B+\delta\left(p_{L} \operatorname{Pr}(\right.$ stays $\mid y=1)[B+R]+\left(1-p_{L}\right) \operatorname{Pr}($ stays $\left.\mid y=0)[B+R]\right)$ with $B+R+\delta \operatorname{Pr}($ stays $\mid y=$ 0) $[B+R]$.

To find the optimal behavior of a government, it is necessary to make assumptions about the peoples' strategy conditional on the realization of $y$, and to check if these assumptions make sense, i.e. they are rational given citizens' beliefs. Note that the citizens will wish to replace the government in some states of the world if the $\operatorname{costs} c(\gamma)$ are small enough (e.g. if they believe that the probability of a low-competence 
government is greater than 0 ), as otherwise governments of all types will choose to misbehave. As replacing the government is not very costly for the citizens, such a strategy weakly dominates the strategy of doing nothing.

The next lemma describes an equilibrium in a continuation game. ${ }^{4}$ Denote by $x_{i j}$ the decision of the government of type $i$ to predate in period $j$, and denote as $y_{j}$ the policy outcome in period $j$. Denote also the people's strategy in period 2 as $s_{2} \mid y_{2} \in\{$ overthrow, not overthrow $\}$.

Lemma 1 If $c(\gamma)$ is small enough then at $t=2$, there is an equilibrium in a continuation game in which:

1. For $R>\delta(B+R)\left(1-p_{H}\right) \gamma$, equilibrium strategies are $x_{H 2}=1, x_{L 2}=1$, and $s_{2} \mid 1=$ not overthrow, $s_{2} \mid 0=$ overthrow;

2. If $\delta(B+R) p_{L} \gamma<R<\delta(B+R)\left(1-p_{H}\right) \gamma$, equilibrium strategies are $x_{H 2}=0, x_{L 2}=1$, and $s_{2} \mid 1=$ not overthrow, $s_{2} \mid 0=$ overthrow;

3. If $\delta(B+R) p_{L} \gamma>R$, equilibrium strategies are $x_{H 2}=0, x_{L 2}=0$, and $s_{2} \mid 1=$ not overthrow, $s_{2} \mid 0=$ overthrow.

Proof. In Appendix.

Here, the equilibrium strategy of people is simple: if they observe $y_{2}=0$, they overthrow the government; otherwise, they do not. If $y_{2}=1$, the posterior probability that the government is of type $H$ increases, as compared with $\mu$, the probability that a new government will be of that type. By contrast, when $y_{2}=0$, then that probability declines. The optimal strategy of the government depends on $\gamma$. For low $\gamma$, all types of government predate; for intermediate values of $\gamma$, only governments of low competence predate; while for high values of $\gamma$, all types of government refrain from predation.

Denote people's strategy in period 1 as $s_{1} \mid y_{1}$. The following proposition describes equilibria which emerge in the original game for different values of $R$ and $\gamma$ (see the summary in Table 1 ).

\footnotetext{
${ }^{4}$ All equilibria in a continuation game are characterized in a working paper version of this paper. To save space, we refrain from presenting them here.
} 
Proposition 1 If $R$ is sufficiently large and $c(\gamma)$ is sufficiently small, the equilibrium set of strategies is the following:

- $x_{L 1}=1, x_{H 1}=1, s_{1} \mid 1=$ not overthrow, $s_{1} \mid 0=$ overthrow if $\gamma$ is sufficiently small,

- $x_{L 1}=1, x_{H 1}=0, s_{1} \mid 1=$ not overthrow, $s_{1} \mid 0=$ overthrow if $\gamma$ is sufficiently large;

If both $R$ and $c(\gamma)$ are sufficiently small, the equilibrium set of strategies is the following:

- $x_{L 1}=1, x_{H 1}=1, s_{1} \mid 1=$ not overthrow, $s_{1} \mid 0=$ overthrow if $\gamma$ is sufficiently small,

- $x_{L 1}=1, x_{H 1}=0, s_{1} \mid 1=$ not overthrow, $s_{1} \mid 0=$ overthrow if $\gamma$ is in intermediate range,

- $x_{L 1}=0, x_{H 1}=0, s_{1} \mid 1=$ not overthrow, $s_{1} \mid 0=$ overthrow if $\gamma$ is sufficiently large.

The corresponding equilibria in a continuation game are described in lemma 1.

Proof. In Appendix.

Clearly, institutions matter. For high values of $\gamma$, or, correspondingly, low values of $R$, all types of government refrain from predation, and institutions perform their role of restricting the behavior of the government. For intermediate values of $\gamma$ and $R$, only governments with high competence refrain from predation, while governments with low competence predate. For small values of $\gamma$, or high values of $R$, all types of government predate, and accountability mechanisms are ineffective.

\subsection{Empirical implications}

The model thus generates a relationship between political risk, economic performance and regime type. Among democracies, we see political restraint and favorable prospects for investment and growth. In unconstrained dictatorships, we witness political predation and few prospects for investment and growth. And among intermediate regimes, we find heterogeneity, both political and economic. 
As we cannot observe the strategies and expectations of the actors, it is difficult to devise direct tests of the model. The logic of the model implies, however, changes in the level of measurable risk that must prevail if the model is correct.

Consider the risk of predation in the second period, given by $\operatorname{Pr}\left(x_{2}=1 \mid y_{1}=i, \widehat{\mu_{1}}\right), i \in\{0,1\}$. Then if the government is not replaced, two propositions follow. These propositions offer opportunities for testing the model.

Proposition 2 After period 1, the risk of predation, as perceived by the citizens, goes up after observing $y_{1}=0$, i.e. $\operatorname{Pr}\left(x_{1}=1\right) \leq \operatorname{Pr}\left(x_{2} \widehat{=1 \mid} y_{1}=0\right)$.

Proof. In Appendix.

Basically, this proposition implies that a growth downturn provides a signal of the government's (in) competence.

More telling, perhaps, is the second implication: that the magnitude of this effect should be greatest in intermediate regimes.

Proposition 3 The estimated risk of predation changes more significantly after observing $y=0$ at intermediate values of $\gamma$.

Proof. In Appendix.

In intermediate regimes, there are incentives for the different types of governments to separate in equilibrium; as a result, growth downturns provide a clearer signal of a government's type. We therefore expect to find economic performance more closely related to the citizen's estimates of the risk of predation in these regimes than in pure democracies or autocracies.

These predictions do not offer a full test of the model, of course; but we should observe these patterns of behavior if the model is correct. 


\section{Empirical Results}

To test the model, we gathered data for 123 countries for the years 1982-2003; the depth of the panel is dictated by the availability of measures of political risk. Using these data, we have identified a set of growth downturns. We show that risk estimates increase after economic downturns. Observing their relationship with measures of risk under different regimes, we also show that the sensitivity of risk to economic performance depends on the nature of political institutions. In particular, we find that after negative economic shocks, average changes in assessments of risk are greatest in "intermediate" regimes.

\subsection{Dependent Variable}

The data come from the IRIS-3 dataset constructed by Steve Knack and Philip Keefer for the Center for Institutional Reform and the Informal Sector (IRIS) at the University of Maryland. The dataset includes scores for six political risk variables: corruption in government, rule of law, bureaucratic quality, ethnic tensions, repudiation of contracts by government, and risk of expropriation. We employ the IRIS measure of expropriation risk and the risk of the government's repudiation of contracts. For ease of interpretation, we transform the indices so that higher values imply higher levels of risk. The variables range from 0 to 10. ${ }^{5}$ Table 4 provides summary statistics for all variables used in the analysis.

\subsection{Independent Variables}

For our independent variables, we provide measures of $\gamma$, or the capacity of citizens to depose their government; a dummy variable to signify economic downturns; and dummies for external economic shocks. In addition, we introduce several control variables to capture time varying characteristics of different

\footnotetext{
${ }^{5}$ In a previous version of this paper, we also employed data from the International Country Risk Guide (ICRG) itself. We choose to withdraw these results, as their indices are based only on ovjective indicators and do not incorporate expectations. The results for ICRG risk indices are consistent with the results we are presenting here and are available in a working paper paper version of this paper.
} 
countries. ${ }^{6}$

\section{Measures of Political Restraint:}

We use the 21 point Polity scale as a proxy for $\gamma$. Less skewed than the democracy or autocracy scale, (see figures 3-5), it enables us to gather our observations into three groups of roughly equal size: autocracies, with Polity $\leq-7$; democracies, with Polity $\geq 7$; and intermediate regimes, with Polity scores in between. ${ }^{7}$ Such a division yields three groups of comparable: 1138 observations of autocracies, 911 observations of intermediate regimes, and 1181 observations of democracies.

We also report the results with small changes in the endpoints for Polity.

As an alternative measure, we use a classification based on Legislative Index of Electoral Competition from the Database on Political Institutions of Beck et al. (2006). The advantage of this index is that we can clearly explain what our cutoffs mean. The drawback is that the distribution of this index is skewed to the right, and some results might appear/disappear mechanically, because of large differences in the size of each regime group (see Fig. 6). Specifically, we use the following cutoff points: 3 (legislature is elected, but only closed list of candidates from one party is allowed) for being autocracy, and 7 (legislature is elected, and the largest party received less than 75 percents of seats) for being a democracy. ${ }^{8}$

\section{Economic Shocks:}

To identify negative shocks, we employ the methodology used by Hausman et al. (2005). We create a "filter" based on yearly growth differences: $\Delta g_{i t}=g_{i t}-g_{i, t-1}$, where $g_{i t}$ is a growth rate of country $i$

\footnotetext{
${ }^{6}$ Characteristics of countries which are constant over time are captured by country fixed effects.

${ }^{7}$ The main reason for using -7 and 7 as thresholds is to divide the sample into three approximately equal groups. We thereby avoid the bias potentially induced by differences in group size.

${ }^{8}$ Beck et al. (2001) provide the following coding for their index: 1 - no legislature; 2 - unelected legislature; 3 - elected, one candidate; 4 - one party, multiple candidates; 5 - multiple parties are legal, but only one won seats (because other parties did not exist, compete, or win seats); 6 - multiple parties competes and won seats (but one party won 75 percent or more of the seats); 7 - the largest party received less than 75 percent of the seats.
} 
during the time period $t$. We label a short term change in the growth rate a negative growth shock when

(1) in the year of shock $\Delta g_{i t}<-2$ ppa (percentage points of growth per annum).

(2) after a shock $g_{i t}<2$ ppa. This restriction prevents counting as a growth collapse a decline from, say, 8 to 5 percent per year.

We then create the variable $s h o c k_{t, t-2}$ which is equal to 1 if a negative economic shock took place in the years $t, t-1$, or $t-2$, and which is equal to 0 otherwise.

Summary statistics appear in Tables 1 and 2 in the Appendix. Countries in Sub-Saharan Africa and the region of Australia and Oceania exhibit the greatest frequency of negative growth shocks, while countries in Western Europe, North America and Asia exhibit the lowest. The average magnitudes of negative changes in growth rates are shown in table 2. Countries in Western Europe and North America have the lowest average magnitudes - the average decrease in their growth rates after a shock is 3.4 percentage points. Countries in Australasia and Oceania yield the largest, with an average decrease of 8.4 percentage points. The results are robust to small changes in the parameters of the filter.

\section{Instrumental Variables:}

Regressions of risk indicators on growth shocks are subject to endogeneity bias: an increase in political risk can spur a growth decline. Because of the persistence in the risk variables, lags of the shock dummies fail to address this problem. We therefore sought exogenous variables that could provide instruments for negative economic shocks and chose the number of natural disasters and the onset of an unexpected decline in the terms of trade.

Data about natural disasters come from Emergency Events Database (EM-DAT) prepared by World Health Organization Collaborating Centre for Research on the Epidemiology of Disasters (CRED). The relevant descriptive statistics appear in Table 3 of the Appendix. The variable "natural disaster" is equal to the number of natural disasters that take place in a given country-year. It ranges from 0 to 12 .

Data on unexpected terms of trade shocks are taken from the database composed by Dani Rodrik. 
He excluded the influence of long-term trends and some macroeconomic fundamentals from a country's current terms of trade, thereby capturing the"unexpected"part of terms of trade volatility. As do Hausman et al. (2005), we construct a dummy variable which takes the value 1 when there is a negative unexpected terms of trade shock that falls in the lowest quartile (25\%) of the distribution and 0 otherwise.

Our empirical strategy can be questioned on the grounds that exogenous events are observable and cannot themselves be attributed to the actions of governments. True, but the disaster itself stands apart from the government's response to it. And while the citizens may spare the government censure for the first, they are likely to form judgments about the government's handling of the second. In addition, while citizens may indeed observe the shock, they may be unable to judge whether its magnitude is sufficient to account for a decline in the growth rate. True again, but the citizens are aware that all governments presiding over a sluggish economy have an incentive to attribute poor economic performance to external causes. Given this, citizens may change their assessment of the government's type during bad times. Therefore, there is no contradiction between our model and our empirical strategy.

\section{Control Variables:}

Given the literature on the relationship between income and democracy (Lipset 1960), we control for the level of GDP per capita using data from the World Development Indicators (WDI). Smaller countries would be more vulnerable to external terms of trade shocks, and vulnerability might decline as population grows. Larger countries might also be more likely to experience natural disasters. In addition, recent literature suggest that countries with larger population are more prone to revolutions (Campante and Do, 2007) and have larger public sector (Alesina and Wacziarg, 1998). We therefore control for the population size, using data from WDI. We also control for trade openness, using the ratio of exports and imports together to country GDP. The data again come from WDI. To control for country's time invariant characteristics, we include country fixed effects. As Bates, Block and Tiefenthaler (1991) and Rodrik (1998) illustrate, there is a correlation between exposure to economic volatility and the size of 
government, so we control for government expenditures as percentage of GDP, from WDI.

\subsection{Preliminary observations}

Our theoretical argument implies that risk is more responsive to economic performance in intermediate regimes. It also implies that the evolution of risk in intermediate regimes differs from that in other types of governments. Taken together, the two implications suggest that intermediate regimes should exhibit higher variance in assessments of risk than would stable democracies or autocracies.

The descriptive statistics suggest that it is the case. Figure 7 captures the variance of expropriation risk by regime type. As can be seen, the middle group, corresponding to intermediate regimes, exhibits the largest variance. By implication, then, the variance of growth rates in the sample should be greater for intermediate regimes than for full democracies or full autocracies. Figure 8 lends support to this claim.

\subsection{Statistical Tests}

Proposition 2 predicts risk should increase after an economic shock. Bayes' rule implies that the contemporary level of risk should depend on its previous value. We therefore estimate a model that includes the lagged value of the dependent variable plus a dummy for economic downturns, control variables, and country fixed effects.

$$
\operatorname{risk}_{i, t+1}=\beta_{0}+\beta_{1} r i s k_{i, t-3}+\beta_{2} \text { shock }_{i ; t, t-2}+\beta_{3} X_{i, t-3}+\eta_{i}+\varepsilon_{i, t+1}
$$

Because annual data on political risk are noisy, we use 3-year period averages. Shock $k_{t, t-2}$ is an indicator variable that is equal 1 if a negative economic shock occurs in the interval $t, t-1$, or $t-2 . X_{t-3}$ is the vector of control variables, which are observed prior to economic shock (i.e. at $t-3$ ).

As an economic decline, shock $k_{i t, t-2}$, may be the consequence of high risk at $t-3$, there is the potential for endogeneity bias. We therefore estimate (2) using a 2SLS procedure, in which shock $k_{i ; t, t-2}$ is instrumented by nat_dst_3 $t^{-}$the number of natural disasters in years $t, t-1$, and $t-2-$ and terms 
of trade shocks tot_shock_3 $3 k_{i ; t, t-2}$ by the number of unexpected term of trade shocks in this period. By construction, the instruments are not correlated with either our control variables $X_{t-3}$, as they are computed in the years preceding the shock, or with our measure of $r i s k_{t-3}$. As we use a fixed effect estimator of (2), the possibility of a correlation between our instruments and unobserved, country-specific effects does not arise. Note that any bias in $\widehat{\beta}_{2}$ that may arise because of the autoregressive term in (2) and the presence of country effects will be negative. If such bias is present, then, it renders our results stronger. ${ }^{9}$

To the extent that we believe that natural disasters and terms of trade shocks are exogenous, our instruments are valid. We test the validity of our instruments by using the Hausman's test of overidentifying restrictions. The null hypothesis - that there are no overidentifying restrictions - implies that instruments are not endogenous to each other. The results suggest that the null hypothesis can not be rejected at $5 \%$ significance level.

Proposition 3 implies that perceptions of risk should depend on the level of $\gamma$, the ability of citizens to change their government. In particular, our theory predicts that the increase of risk after an economic shock should be greatest in intermediate regimes.

By using interaction terms, we can combine the tests of the two hypotheses into one model:

$$
\begin{aligned}
\operatorname{risk}_{i, t+1}= & \beta_{0}+\beta_{1} \text { risk }_{i, t-3}+\beta_{2} \text { shock }_{i ; t, t-2} * d_{i 1, t-3}+\beta_{3} \text { shock }_{i ; t, t-2} * d_{i 2, t-3}+ \\
& +\beta_{4} \text { shock }_{i ; t, t-2} * d_{i 3, t-3}+\beta_{5} d_{i 1, t-3}+\beta_{5} d_{i 2, t-3}+\beta_{6} X_{i, t-3}+\eta_{i}+\varepsilon_{i, t+1}
\end{aligned}
$$

\footnotetext{
${ }^{9}$ Note that in this specification, the first difference estimator of (2) is not consistent (Bond 2002). We address the possibility of endogeneity by instrumenting $\operatorname{shock}_{i ; t, t-2}$, and by noting that the correlation of lagged dependent variable with the error term is negative (see Nickel 1981 for a formal proof). Arellano-Bond (1991) and Blundell-Bond (1998) offer an alternative way of addressing this probelm and we applied them to estimate (2). We do not report the corresponding GMM estimates as the corresponding regressor matrix is nearly singular, implying that small changes in assumed values of the estimators would result in large changes in estimated coefficients, and standard errors cannot be consistently estimated. The signs of the coefficients in GMM estimation and their significance levels in some specifications are consistent with those reported in the paper.
} 
where dummy variables $d_{i j, t-3}$ denote being in group $j$ of political regimes at $t-3$ (group 1 is autocracies, group 2 is intermediate regimes, and group 3 democracies). The coefficients $\beta_{2}$ through $\beta_{4}$ provide a measure of the differential impact of growth collapses among the three categories of regimes. The interactions between $s h o c k_{i ; t, t-2}$ and the dummies for political regime are instrumented by the interactions between these dummies and natural disasters nat_dst_ $3_{t}$ and terms of trade shocks tot_shock_ $3_{t}$. Our model takes $d_{i j, t-3}$ as given, so we do not seek instruments for this term. Proposition 3 implies that the coefficient $\beta_{3}$ for the interaction with intermediate regime is positive and significant, while coefficients $\beta_{2}$ and $\beta_{4}$ should be 0 .

\subsection{Findings}

Basic results

Table 5 shows the results of an estimation of model (2) that incorporates fixed effects and instrumental variables. Columns 1-2 present the results of OLS estimation, while columns 3-4 report the results of IV estimation. The dummy for a negative shock is the coefficient of interest. By Proposition 2, the coefficient should be negative and significant. We find that the IV estimates are of the expected sign and significant, which lends support to our model. The OLS coefficients are smaller than IV coefficients, and neither is significant. According to the estimates, the impact of economic downturns on risk assessments is sizable, being approximately $0.5-0.6$ of a standard deviation for both measures.

\section{Interactions}

Table 6 reports estimates of model (3). For the IV specifications, the coefficients for the interaction between economic shocks and regime type are significant for intermediate regimes, while none are significant for the interactions with autocracy or democracy. Figure 9 illustrates the behavior of the corresponding coefficients for different measures of risk. Again, the OLS coefficient remain smaller than those for the IV estimates and most are not significant. By column (3), an economic downturn increases the risk of expropriation in an intermediate regime by 2.98 risk points, equal to approximately 1.1 standard deviations 
of the dependent variable. Similarly, an economic downturn increases the risk of repudiation of contracts by 1.85 risk points, which is approximately equal to 0.55 standard deviations of the dependent variable. Both coefficients are far larger than are those for autocracies or democracies. The data thus confirm that, as implied by our model, the level of perceived political risk increases after growth shocks and that this effect is significantly more pronounced for intermediate regimes.

\section{Alternative classification of regimes}

The results of Table 6 rely on Polity IV-based classification of regimes into democracies, autocracies, and intermediate regimes. Alternatively, we can use the classification that relies on more intuitive institutional criteria based on the Database of Political Institutions of Beck et al. (2006). Table 7 reports the results of this exercise. The IV coefficients for the interaction of economic shocks with an intermediate regime are significant at the $5 \%$ level for both dependent variables. By column (3), an economic downturn increases the risk of expropriation in an intermediate regime by 3.99 risk points, which is equal to 1.5 standard deviations of the dependent variable. Similarly, by column (4) an economic downturn increases the risk of repudiation of contracts by 3.70 risk points, which is equal to 1.1 standard deviations of dependent variable. Overall, the results of Table 7 are consistent with those of Table 6 .

No government changes (main results)

Note that between $t-3$ and $t+1$ the government could change. Were that the case, the evidence in Tables 5-7 would fail to provide a "clean" test of Propositions 2 and 3, and the coefficients would be subject to attenuation bias. In response to this possibility, we re-estimate equation (3) while restricting our attention to countries in which the governments did not change between $t-2$ and $t .{ }^{10}$ The results are presented in Table 8. Consistent with the possibility of attenuation bias, the IV coefficients exhiibit larger numerical values and higher levels of significance (1\%), despite being computed from smaller samples, as compared with Table 6 . The OLS coefficients are still much smaller than those computed when using instrumental variables. The IV coefficients change to 3.10 risk points for expropriation risk (1.1 standard

\footnotetext{
${ }^{10}$ Risk variables are computed in the beginning of year $t+1$, so we should not care about year $t+1$.
} 
deviations) and 2.58 risk points for the risk of repudiation of contracts ( 0.7 standard deviations). As Table 8 provides a more accurate test of our theoretical model, as compared with Table 6 , we consider these results as the principal results of the paper.

Note, in closing, that Proposition 2 allows for an alternative interpretation. In the model of Johnson et al. (2000), in times of crisis, managers face stronger incentives to expropriate from shareholders, as the marginal product of capital declines; a similar logic can hold for governments. In a similar vein, Paltseva (2008) argues that as capital accumulation continues, political predation becomes more attractive, as the marginal product of investment goes down. Our second prediction, however, follows from no other model and therefore offers the stronger test of our model. ${ }^{11}$

\subsection{Robustness checks}

Table 9 reports the robustness of our results to changes in the cutoff points of the Polity index. The results are consistent with Table 8, and the IV coefficients remain significant at the $5 \%$ level. The coefficients are larger in columns 7-8 as compared with column 5-6, probably because the category of intermediate regimes is itself larger, suggesting that our concerns about the varying size of the subsample were well placed. The results in columns 1-6 remain very close to the original results in Table 6.

We confirm that our results still hold when interacting the growth downturn dummy with Polity and Polity squared. In addition, we obtained the strongest and most highly significant coefficient for Polity

\footnotetext{
${ }^{11}$ Note too that in our analysis, we focus only on the equilibria in which the citizens want to replace the governments more often after bad economic outcomes. This is consistent with the literature on retrospective voting, e.g. Kiewiet and Rivers (1984), and with the assumption of performance voting in accountability models, e.g. Barro (1973), Ferejohn (1991), Persson and Tabellini (2000), Humpreys and Bates (2006). Relevant too is that empirical evidence suggests that citizens may in fact punish politicians for bad luck and reward them for good. Using historical U.S. data, Achen and Bartels (2002) find that voters regularly punish governments for droughts, floods, and shark attacks. Wolfers (2002) finds that voters in oil-producing states tend to re-elect incumbent governors during oil price rises and vote them out of office when the oil price drops.
} 
squared in the intermediate range of the Polity index. Our results are also robust to the exclusion of former Soviet Union and Eastern European countries.

Given the evidence contained in the literature, it is possible that intermediate regimes may differ from others not because their institutions are different in structure but because they are younger in age and therefore less institutionalized (Huntington 1968). To explore this possibility, we re-estimated the estimates in Table 8 while controlling for the age of political parties, the number of years the chief executive has remained in office, and the number of years since independence. The results remain unchanged.

It is also possible that countries with higher population density or higher fraction of urban population are, other things being equal, more technologically advanced (Kremer 1993) and, therefore, are more prone to economic shocks. We checked that our results are robust to inclusion of these variables.

We also find that the results of Table 8 are robust to different ways of clustering standard errors. The results do not substantially change if clustering by country, year, or region-year is used.

One could argue that government spending should not be used as control as it is itsef endogenous. Our results are robust to dropping government spending from the list of controls (see results in a working paper version of this paper).

Finally, we find that our results do not change if we control for foreign aid and for the fraction of military in labor force.

\section{Conclusion}

Our model implies that in intermediate regimes chance events can lead to changes in expectations and thus in the political and economic choices that people make. Both within-country and cross-country variation will therefore be high. Our model thus points to systematic forces that can generate what previously had appeared to be unsystematic and unpredictable behavior in such regimes.

Upon reflection, an additional implication flows from our analysis. The argument suggests the existence 
of three kinds of countries. First come those in which $\gamma$ is high. In such countries, our argument implies, political expectations can have little effect on growth. Investors are protected from government predation by the fact that should a government predate, it would be driven from office. Expectations are therefore already favorable.

Secondly there are countries in which $\gamma$ is low. Such countries are run by dictators whom the people cannot overthrow. In these countries expectations are bad, and governments have little incentive to modify them because the expectations will not improve even should they choose to behave with restraint.

It is among countries in the middle range of $\gamma$ where growth responds to changes in expectations. According to our model, should a government behave opportunistically, or the country be hit with an external shock, then the perceived level of risk will rise and the rate of growth decline. On the other hand, in this range of $\gamma$, there are economic payoffs for the exercise of political restraint. Among such countries, the behavior of governments can make a difference. They can induce economic growth. They can do so by shaping political expectations.

\section{References}

Abernethy, D. B. (2000). The Dynamics of Global Dominance: European Overseas Empires, 1415-1980. New Haven and London: Yale University Press.

Acemoglu, D., S. Johnson, J. Robinson, and Y. Thaicharoen (2003, January). Institutional causes, macroeconomic symptoms: volatility, crises and growth. Journal of Monetary Economics 50(1), $49-123$.

Acemoglu, D. and J. Robinson (2001). The colonial origins of comparative development. American Economic Review 91, 1369-1401.

Acemoglu, D. and J. Robinson (2005). Economic origins of dictatorship and democracy. Cambridge: Cambridge University Press. 
Acemoglu, Daron, R. J. and T. Verdier (2004). Kleptocracy and divide-and-rule: A model of personal rule. Journal of the European Economic Association Papers and Proceedings 2, 162-192.

Achen, C. H. (2000). Why lagged dependent variables can suppress the explanatory power of other independent variables. Paper presented at the 2000 Annual Meeting of American Political Science Association.

Achen, C. H. and L. M. Bartels (2002). Blind retrospection: Electoral responses to droughts, flu, and shark attacks. Paper presented at the 2002 Annual Meeting of the American Political Science Association.

Alesina, A. and R. Wacziarg (1998, September). Openness, country size and government. Journal of Public Economics 69(3), 305-321.

Arellano, M. and S. R.Bond (1991). Some tests of specification for panel data: Monte carlo evidence and an application to employment equations. Review of Economic Studies 58(2), 277-297.

Austen-Smith, D. and J. S. Banks (1989). Models of Strategic Choice in Politics, Chapter Electoral accountability and incumbency, pp. 121-148. University of Michigan Press.

Baliga, S., D. Lucca, and T. Sjostrom (2009, August). Domestic political survival and international conflict: Is democracy good for peace?

Banks, J. S. and R. K. Sundaram (1993). Political Economy: Institutions, Information, Competition, and Representation, Chapter Adverse selection and moral hazard in a repeated elections model. Cambridge University Press.

Barro, R. (1973). The control of politicians. Public Choice 14, 19-42.

Bates, R. H., P. L. Brock, and J. Tiefenthaler (1991, Winter). Risk and trade regimes: Another exploration. International Organization 45(1), 1-18.

Beck, T., G. Clarke, A. Groff, P. Keefer, and P. Walsh (2001). New tools in comparative political 
economy: The database of political institutions. World Bank Economic Review 15(1), 165-176.

Beck, T., P. E. Keefer, and G. R. Clarke (2006). Database on political institutions.

Besley, T. (2006). Principled Agents? The Political Economy of Good Government. Oxford: Oxford University Press.

Besley, T. and M. Kudamatsu (2008). Institutions and Economic Performance, Chapter Making Autocracy Work, pp. 452-510. Princeton University Press.

Besley, T. and T. Persson (2011). Pillars of Prosperity: The Political Economics of Development Clusters. Princeton, NJ: Princeton University Press.

Blundell, R. W. and S. R. Bond (1998). Initial conditions and moment restrictions in dynamic panel models. Journal of Econometrics 87, 115-143.

Boix, C. and M. Svolik (2009). The foundations of limited authoritarian government: Institutions and power-sharing in dictatorships. Papers 10-21-2009, Princeton University, Research Program in Political Economy.

Bueno de Mesquita, B., A. Smith, R. M. Siverson, and J. D. Morrow (2003). The Logic of Political Survival. MIT Press.

Campante, F. R. and Q.-A. Do (2007). Inequality, redistribution, and population. Mimeo.

Collier, D. and S. Levitsky (1997). Democracy with adjectives. World Politics 49, 430-451.

Cox, G. (2009). Authoritarian elections and leadership succession, 1975-2004. Paper Presented to the 2009 Annual Meeting of he American Political Science Association.

Cuberes, D. and M. Jerzmanowski (2009, October). Democracy, diversification and growth reversals. Economic Journal 119(540), 1270-1302.

Easterly, W., M. Kremer, L. Pritchet, and L. Summers (1993). Good policy or good luck? country growth performance and temporary shocks. Journal of Monetary Economincs 32(3), 459-483. 
EM-DAT (2008). The ofda/cred international disaster database.

Epstein, D. L., R. H. Bates, J. Goldstone, I. Kristensen, and S. O'Halloran (2006). Democratic transitions. American Journal of Political Science 59, 551-69.

Fearon, J. and D. Laitin (2003). Ethnicity, insurgency, and civil war. American Political Science Review 97(1), 75-90.

Ferejohn, J. (1991). Democracy, Accountability, and Representation, Chapter Accountability and Authority: Toward a Theory of Political Accountability. Cambridge University Press.

Gandhi, J. (2006). Political Instituions under Dictatorship. New York: Cambridge University Press.

Gandhi, J. and Przeworski (2006). Cooperation, cooptation, and rebellion under dictaorships. Economics and Politics 18(1), 1-26.

Gandhi, J. and A. Przeworski (2007). Authoritarian institutions and the survival of autocrats. Comparative Political Studies 40(11), 1279-301.

Gates, S., N. P. Gleditsch, and H. Hegre (2001). Democratization in Eastern and Central Europe, Chapter Democracy and Civil Conflict after the Cold War, pp. 185-194. Boulder, CO: East European Monographs.

Geddes, B. (2003). Paradigms and Sand Castles. Ann Arbor: University of Michigan Press.

Gehlbach, S. and P. Keefer (2008). Investment without democracy: Ruling party institutuonalization and credible commitment in autocracies. Working Paper.

Gehlbach, S. and P. Keefer (2009). Private investment and the institutionalization of collective action in autocracies: Ruling parties, militaries and bureacracies. Paper Presented to the 2009 Annual Meeting of he American Political Science Association.

Glaeser, E. L., R. L. Porta, F. L. de Silanes, and A. Shleifer (2004, 09). Do institutions cause growth? Journal of Economic Growth 9(3), 271-303. 
Goldstone, J., M. Marshall, R. Bates, and D. Epstein (2003). State failure task force project, phase iii report. McLean, VA: Science Applications International Corporation.

Haber, S. (2006). The Oxford Handbook of Political Economy, Chapter Authoritarian Government. Oxford University Press.

Haber, S., A. Razo, and N. Maurer (2003). he Politics of Property Rights: Political Instability, Credible Commitments, and Economic Growth in Mexico, 1876-1929. New York: Cambridge University Press.

Hausman, Ricardo, L. P. and D. Rodrik (2005). Growth accelerations. Journal of Economic Growth 10, 303-329.

Hegre, H. (2004). The duration and termination of civil war. Journal of Peace Research 41(3), 243-252.

Holmstrom, B. (1979). Moral hazard and observability. Bell Journal of Economics 10(1), 74-91.

Humphreys, M. and R. H. Bates (2005). Political institutions and economic policies. British Journal of Political Science 35(3), 403-428.

Huntington, S. P. (1968). Political Order in Changing Societies. New Haven and London: Yale University Press.

Huntington, S. P. (1991). The Third Wave. Norman, OK: Oklahoma University Press.

ICRG (2006). Dataset on country risks.

Jerzmanowski, M. (2006, December). Empirics of hills, plateaus, mountains and plains: A markovswitching approach to growth. Journal of Development Economics 81(2), 357-385.

Johnson, S., P. Boone, A. Breach, and E. Friedman (2000). Corporate governance in the asian financial crisis. Journal of Financial Economics 58(1-2), 141-186.

Jones, B. F. and B. A. Olken (2005, August). Do leaders matter? national leadership and growth since world war ii. The Quarterly Journal of Economics 120(3), 835-864. 
Keefer, P. and S. Knack. The political dimension of economic growth, Chapter Political stability and economic stagnation.

Kenyon, T. and M. Naoi (2010). Policy uncertainty in hybrid regimes - evidence from firm level surveys. Comparative Political Studies 43(6).

Kiewiet, D. R. and D. Rivers (1984). A retrospective on retrospective voting. Political Behavior 6, 369-393.

Knack, S. and P. Keefer (1995). Institutions and economic performance: Cross-country tests using institutional measures. Economics and Politics 7(3), 207-27.

Knack, S. and P. Keefer (1998). Iris-3: File on international country risk guide (icrg) data. 3rd edition.

Kremer, M. (1993, August). Population growth and technological change: One million b.c. to 1990. The Quarterly Journal of Economics 108(3), 681-716.

Levitsjy, S. and L. Way (2002). The rise of competitive authoritarianism. Journal of Democracy 13(2), $51-65$

Lipset, S. M. (1960). Political Man. Garden City NY: Doubleday.

Magaloni, B. (2006). Voting for Autocracy. New York: Cambridge University Press.

Marshall, M. G. and K. Jaggers (2008). Polity iv project: Political regime characteristics and transitions, $1800-2008$.

Nickel, S. (1981). Biases in dynamic models with fixed effects. Econometrica 49, 1417ñ1426.

North, D. C. and B. R. Weingast (1989). Constitutions and commitment: The evolutions of institutions governing public choice in seventeenth-century england. Journal of Economic History 69, 803-832.

PadrÛ i Miquel, G. (2007). The control of politicians in divided societies: The politics of fear. Review of Economic Studies 74(4), 1259-1274.

Paltseva, E. (2008). Autocracy, devolution and growth. Working Paper. 
Persson, T. and G. Tabellini (2000). Political Economics. Cambridge, MA: MIT Press.

Pop-Eleches, G. and G. Robertson (2009). Elections, information, and liberalization in the post-cold war era. Paper presented at the 2009 Annual Meeting of American Political Science Association.

Pritchett, L. (2000). Understanding patterns of economic growth: Searching for hills among plateaus, mountains, and plains. World Bank Economic Review 14(2), 221-250.

Przeworski, A., M. Alvarez, J. A. Chiebub, and F. Limongi (2000). Democracy and Development. New York: Cambridge University Press.

Ramey, G. and V. A. Ramey (1995, December). Cross-country evidence on the link between volatility and growth. American Economic Review 85(5), 1138-51.

Rodrik, D. (1991). Policy uncertainty and private investment in developing countries. Journal of Development Economics 36(2), 229-243.

Rodrik, D. (1998, October). Why do more open economies have bigger governments? Journal of Political Economy 106(5), 997-1032.

Rodrik, D. (1999, December). Where did all the growth go? external shocks, social conflict, and growth collapses. Journal of Economic Growth 4(4), 385-412.

Rodrik, D. (2000, May). Participatory politics, social cooperation, and economic stability. American Economic Review 90(2), 140-144.

Wolfers, J. (2002, March). Are voters rational? evidence from gubernatorial elections. Research papers, Stanford University, Graduate School of Business. 


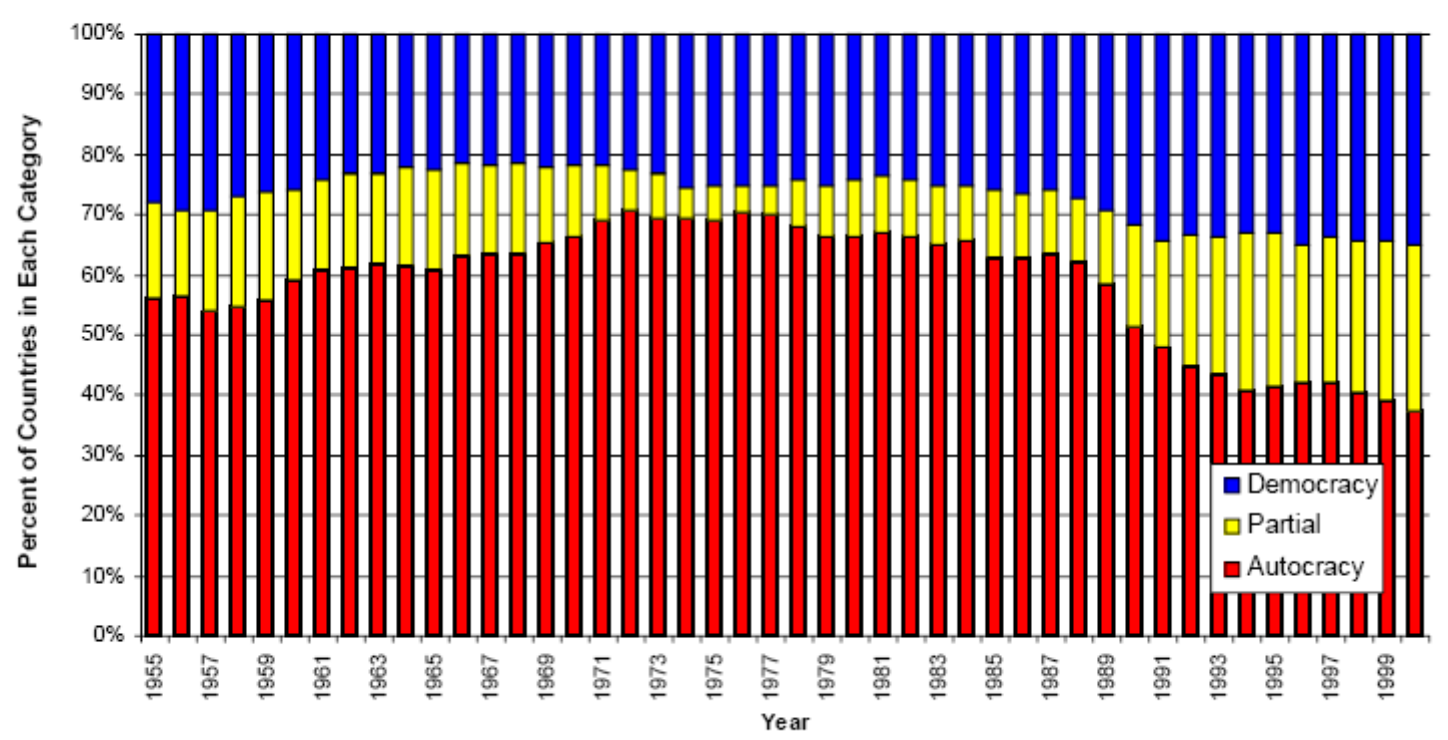

Figure 1. World Democratization Trends, 1955-2000. Reproduced from Epstein, Bates, et al. (2006)

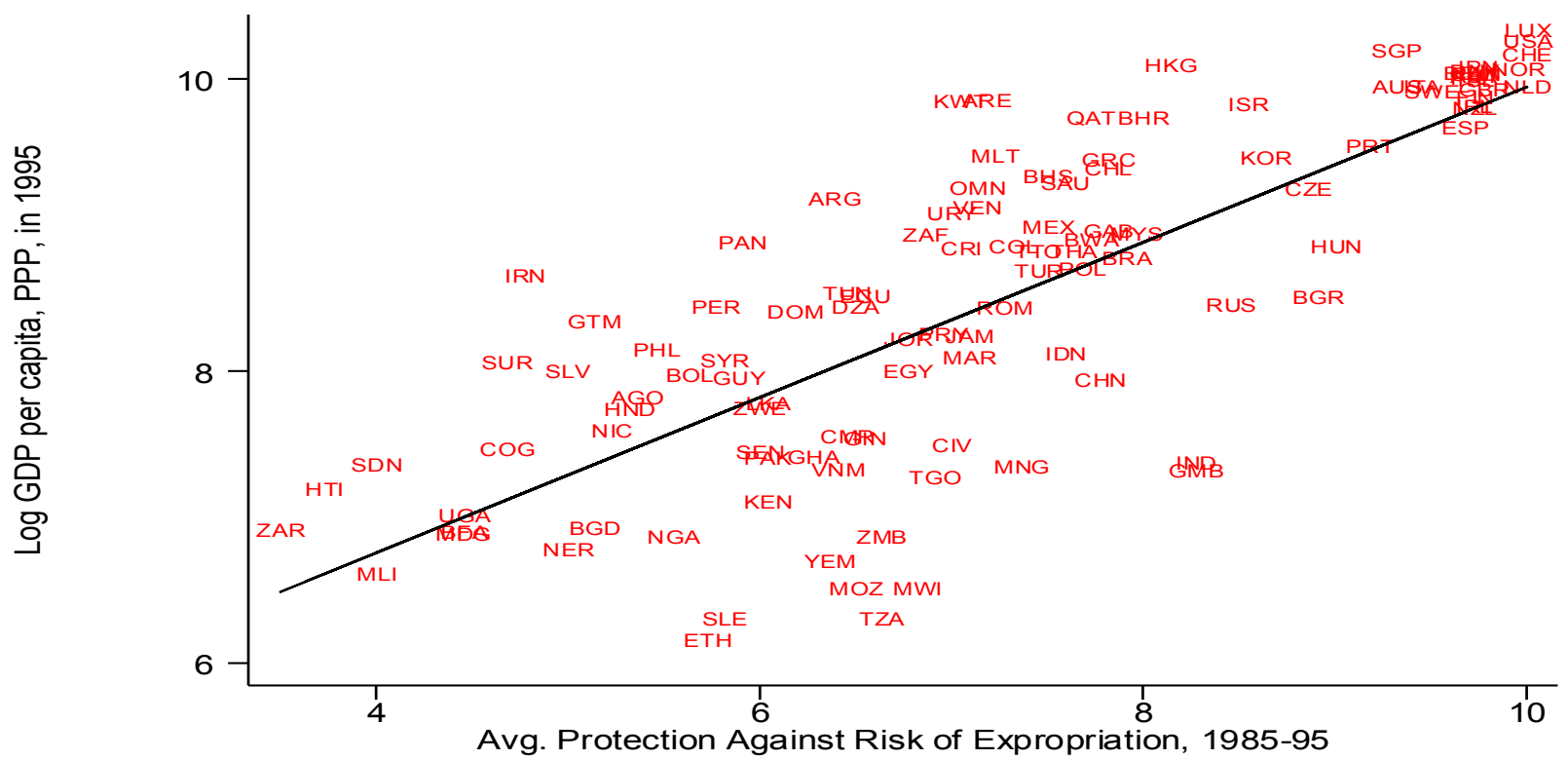

Figure 2. Reproduced from Acemoglu, Daron, Simon Johnson and James A. Robinson (2001) "The Colonial Origins of Comparative Development: An Empirical Investigation” American Economic Review , 91, 1369-1401. 


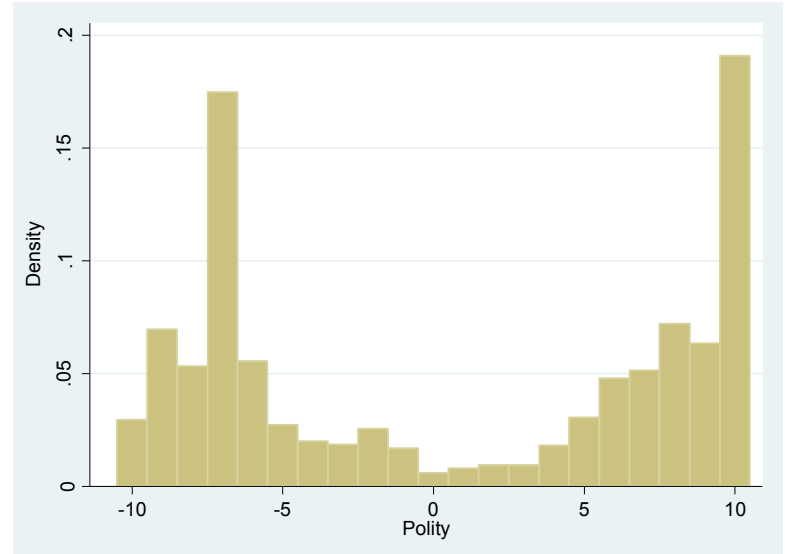

Figure 3 Histogram of Polity variable, 1982-2003 (Polity=Democracy-Autocracy)

Source: Polity IV Project

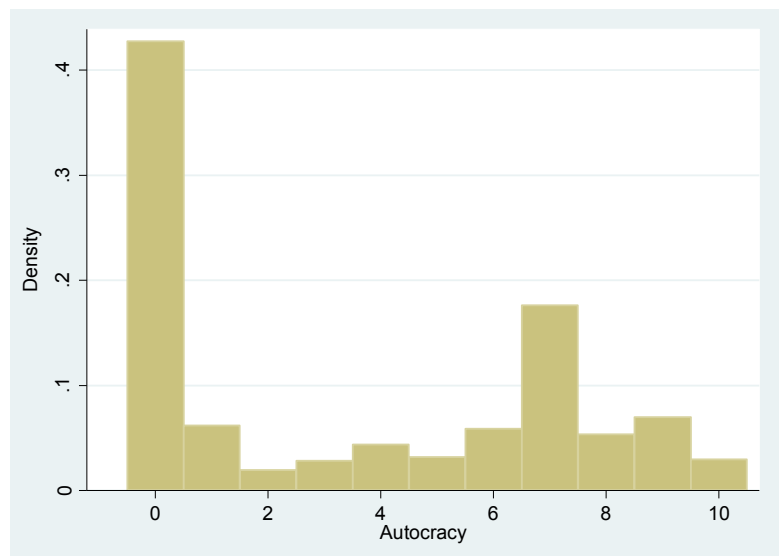

Figure 5. Histogram of Autocracy variable, 1982-2003 Source: Polity IV Project

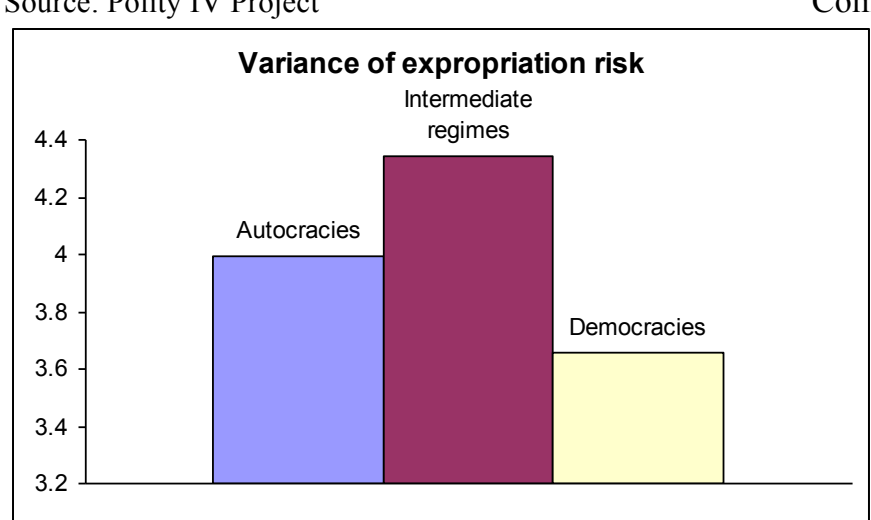

Figure 7. Variance of expropriation risk, by regime type, 1982-2003 Source: IRIS-3, Polity IV Project, authors' calculations.

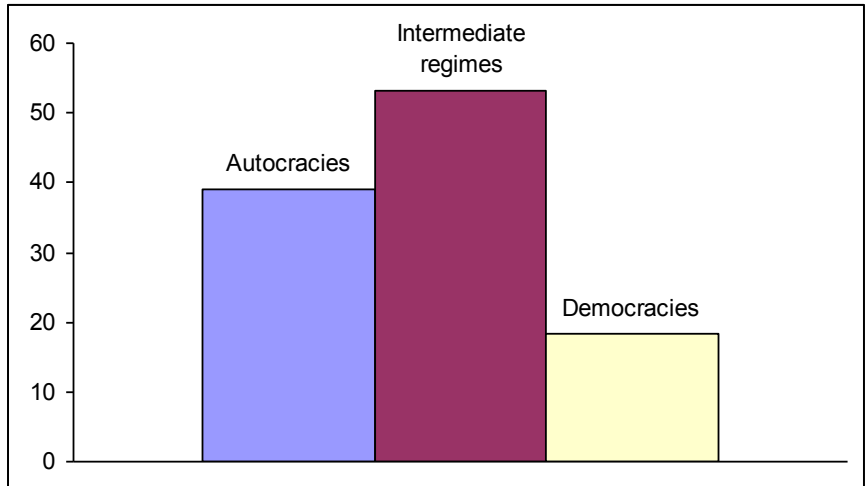

Figure 8 . Variance of growth rate, by regime type.

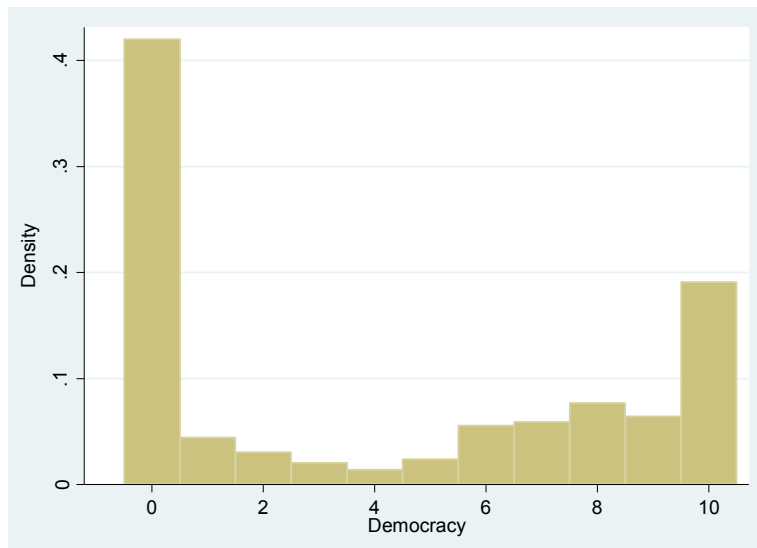

Figure 4. Histogram of Democracy variable, 1982-2003 Source: Polity IV Project

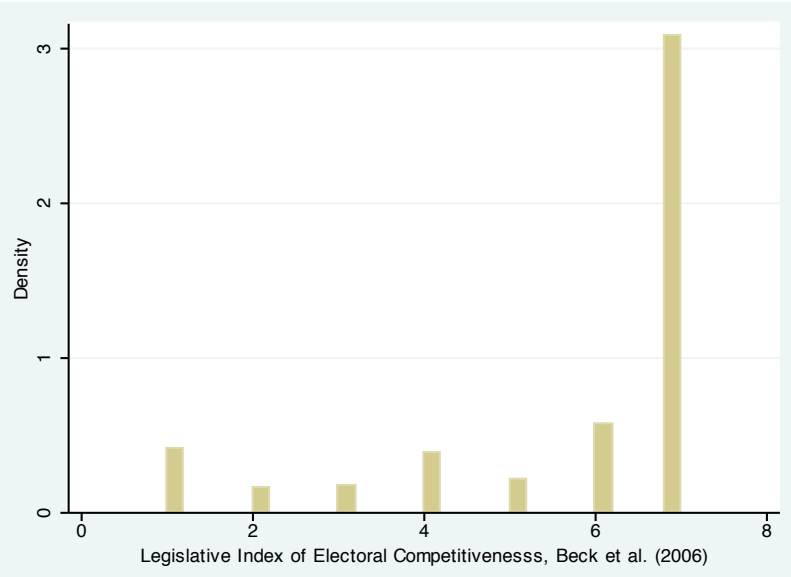

Figure 6. Histogram of Legislative Index of Electoral Competitiveness. Source: Beck et al. (2006) 
Source: WDI 2005, Polity IV Project, authors' calculations.

\section{Expropriation risk}

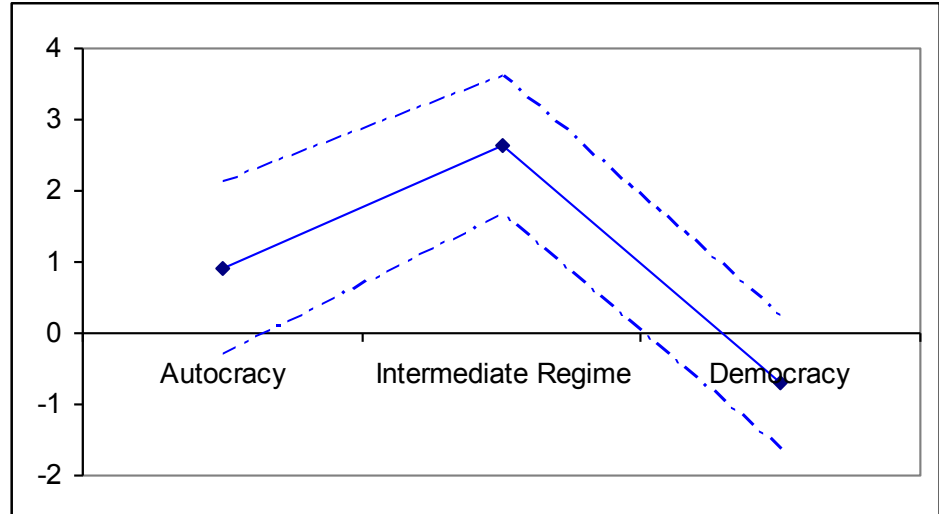

Risk of repudiation of contracts

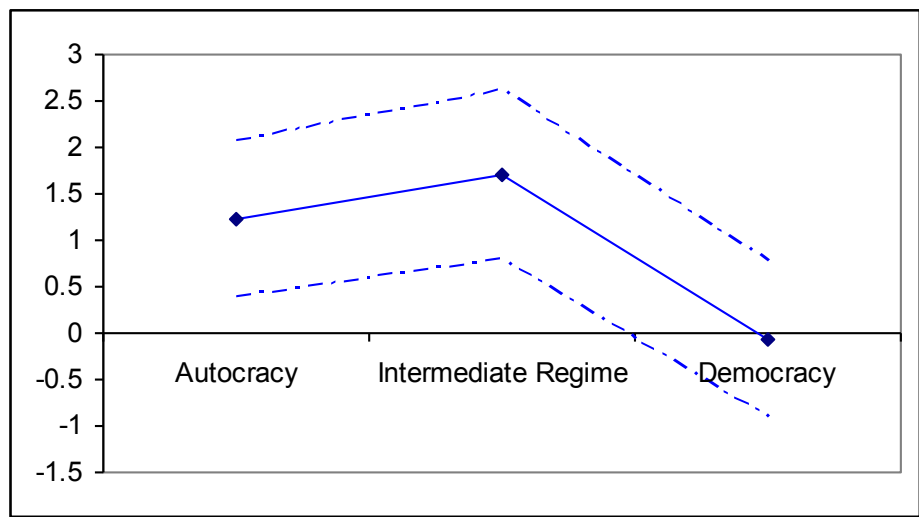

Figure 9. Regression coefficients for collapse effect on risk variables as a function of political regime. Based on the regression from table 6 . 
Table 1. Equilibria in a game between the government and the citizens. The results of Proposition 1.

\begin{tabular}{|l|l|l|l|}
\hline & $\gamma$ is small & $\gamma$ is intermediate & $\gamma$ is large \\
\hline $\begin{array}{l}R \text { is } \\
\text { small }\end{array}$ & $\begin{array}{l}\mathrm{x}_{\mathrm{L} 1}=1, \mathrm{x}_{\mathrm{H} 1}=1, \mathrm{~s}_{1} \mid 1=\text { not } \\
\text { overthrow, } \mathrm{s}_{1} \mid 0=\text { overthrow }\end{array}$ & $\begin{array}{l}\mathrm{x}_{\mathrm{L} 1}=1, \mathrm{x}_{\mathrm{H} 1}=0, \mathrm{~s}_{1} \mid 1=\text { not } \\
\text { overthrow, } \mathrm{s}_{1} \mid 0=\text { overthrow }\end{array}$ & $\begin{array}{l}\mathrm{x}_{\mathrm{L} 1}=0, \mathrm{x}_{\mathrm{H} 1}=0, \mathrm{~s}_{1} \mid 1=\text { not } \\
\text { overthrow, } \mathrm{s}_{1} \mid 0=\text { overthrow }\end{array}$ \\
\hline$R$ is & $\mathrm{x}_{\mathrm{L} 1}=1, \mathrm{x}_{\mathrm{H} 1}=1, \mathrm{~s}_{1} \mid 1=$ not & $\mathrm{x}_{\mathrm{L} 1}=1, \mathrm{x}_{\mathrm{H} 1}=0, \mathrm{~s}_{1} \mid 1=$ not & $\mathrm{x}_{\mathrm{L} 1}=1, \mathrm{x}_{\mathrm{H} 1}=0, \mathrm{~s}_{1} \mid 1=$ not \\
large & overthrow, $\mathrm{s}_{1} \mid 0=$ overthrow & overthrow, $\mathrm{s}_{1} \mid 0=$ overthrow & overthrow, $\mathrm{s}_{1} \mid 0=$ overthrow \\
\hline
\end{tabular}

Table 2. Economic shocks by region.

A: Negative economic shocks, by region, 1982-2003

\begin{tabular}{lcc}
\hline World Bank region & Number of collapses & $\begin{array}{c}\text { Unconditional } \\
\text { probability of } \\
\text { having collapse }\end{array}$ \\
\hline Australia and Oceania & 42 & .286 \\
Center, South and East Asia & 69 & .145 \\
Eastern Europe/Former USSR & 89 & .211 \\
Latin America & 184 & .226 \\
North Africa/Middle East & 115 & .258 \\
Sub-Saharian Africa & 287 & .262 \\
Western Europe/North America & 75 & .140 \\
\hline Total & 861 & .219
\end{tabular}

Source: WDI 2005, authors' calculations

B. Average growth variables for economic shocks, by region, 1982-2003

\begin{tabular}{lccc}
\hline WB Region & Average growth before & Average growth after & Average growth change \\
\hline Australia and Oceania & 4.746 & -3.653 & -8.399 \\
Center, South and East Asia & 3.793 & -2.308 & -6.101 \\
Eastern Europe/Former USSR & -.962 & -9.524 & -8.562 \\
Latin America & 2.797 & -3.577 & -6.374 \\
North Africa/Middle East & 3.316 & -4.133 & -7.449 \\
Sub-Saharian Africa & 2.169 & -5.404 & -7.573 \\
Western Europe/North America & 2.970 & -.4362 & -3.406 \\
\hline Total & 2.458 & -4.503 & -6.962 \\
\hline
\end{tabular}

Source: WDI 2005, authors' calculations

Table 3. Natural disasters counted for disaster variable

\begin{tabular}{cc}
\hline Disaster type & Occurrence, 1980-2003 \\
\hline Earthquake & 590 \\
Drought & 496 \\
Extreme Temperature & 223 \\
Flood & 1978 \\
Slides & 343 \\
Volcano & 104 \\
Wave / Surge & 15 \\
Wind Storm & 1685
\end{tabular}

Source: Emergency Disasters Database, EM-DAT 2006 
Table 4. Summary statistics and sources of data

\begin{tabular}{|c|c|c|c|c|c|c|}
\hline Variable & Source & Observations & Mean & Std. Dev. & Min & $\operatorname{Max}$ \\
\hline Expropriation risk & IRIS-3 & 1945 & 2.91 & 2.309 & 0 & 9.5 \\
\hline $\begin{array}{l}\text { Risk of repudiation of } \\
\text { contracts }\end{array}$ & IRIS-3 & 1945 & 3.57 & 2.343 & 0 & 9.5 \\
\hline Government stability & ICRG & 2453 & 7.31 & 2.453 & 0 & 12 \\
\hline Polity & Polity IV & 3688 & 0.74 & 7.592 & -10 & 10 \\
\hline Autocracy dummy & $\begin{array}{l}\text { Polity IV, } \\
\text { calculations }\end{array}$ & 3230 & 0.35 & 0.478 & 0 & 1 \\
\hline Intermediate regime dummy & $\begin{array}{l}\text { Polity IV, } \\
\text { calculations }\end{array}$ & 3230 & 0.28 & 0.450 & 0 & 1 \\
\hline Democracy dummy & $\begin{array}{l}\text { Polity IV, } \\
\text { calculations }\end{array}$ & 3230 & 0.37 & 0.482 & 0 & 1 \\
\hline Collapse dummy & $\begin{array}{l}\text { WDI 2005, } \\
\text { calculations }\end{array}$ & 4179 & 0.22 & 0.416 & 0 & 1 \\
\hline Collapse in previous 3 years & $\begin{array}{l}\text { WDI } 2005 \\
\text { calculations }\end{array}$ & 4186 & 0.55 & 0.497 & 0 & 1 \\
\hline Natural disasters & $\begin{array}{l}\text { EM-DAT, } \\
\text { calculations }\end{array}$ & 5643 & 1.00 & 2.401 & 0 & 33 \\
\hline $\begin{array}{l}\text { Natural disasters in previous } \\
3 \text { years }\end{array}$ & $\begin{array}{l}\text { EM-DAT, } \\
\text { calculations }\end{array}$ & 5137 & 2.99 & 6.802 & 0 & 93 \\
\hline $\begin{array}{l}\text { Negative term of trade shock } \\
\text { dummy }\end{array}$ & $\begin{array}{l}\text { Rodrik (1999), } \\
\text { calculations }\end{array}$ & 5643 & 0.07 & 0.263 & 0 & 1 \\
\hline $\begin{array}{l}\text { Negative term of trade shocks } \\
\text { in previous } 3 \text { years }\end{array}$ & $\begin{array}{l}\text { Rodrik (1999), } \\
\text { calculations }\end{array}$ & 5137 & 0.25 & 0.572 & 0 & 3 \\
\hline Log (GDP per capita) & WDI 2005 & 3924 & 8.20 & 1.135 & 5.63 & 11.08 \\
\hline Openness & WDI 2005 & 3387 & 79.92 & 45.546 & 1.53 & 296.38 \\
\hline Log (Population) & WDI 2005 & 5049 & 15.20 & 2.086 & 9.89 & 20.97 \\
\hline $\begin{array}{l}\text { Vulnerability to natural } \\
\text { disasters }\end{array}$ & $\begin{array}{l}\text { EM-DAT, } \\
\text { calculations }\end{array}$ & 5643 & 1.00 & 2.025 & 0 & 17.42 \\
\hline Government change dummy & $\begin{array}{c}\text { Leadership } \\
\text { duration } \\
\text { database, PITF }\end{array}$ & 4173 & 0.16 & 0.369 & 0 & 1 \\
\hline $\begin{array}{l}\text { Government consumption } \\
\text { expenditures, \% GDP }\end{array}$ & WDI 2006 & 3973 & 16.86 & 7.517 & 1.375 & 76.22 \\
\hline Average party age & DPI 2006 & 2663 & 31.198 & 28.04 & 1 & 183 \\
\hline Age of regime & $\begin{array}{l}\text { Databanks } \\
2010\end{array}$ & 4173 & 7.177 & 8.385 & 0 & 48 \\
\hline Urban population, \% & WDI 2005 & 3560 & .507 & 236 & .042 & 1 \\
\hline Population density & WDI 2005 & 3350 & 141.86 & 449.23 & 1.158 & 6826.23 \\
\hline Foreign aid, \% GNI & WDI 2005 & 3520 & 8.629 & 13.66 & -.689 & 242.28 \\
\hline $\begin{array}{l}\text { Military personnel, \% labor } \\
\text { force }\end{array}$ & WDI 2005 & 2490 & 1.898 & 2.284 & .059 & 29.4 \\
\hline Years since independence & & 3467 & 147.38 & 344.8 & -12 & 2556 \\
\hline Autocracy dummy & $\begin{array}{l}\text { DPI, } \\
\text { calculations }\end{array}$ & 3499 & .232 & .422 & 0 & 1 \\
\hline Intermediate regime dummy & $\begin{array}{l}\text { DPI, } \\
\text { calculations }\end{array}$ & 3499 & .273 & .445 & 0 & 1 \\
\hline Democracy dummy & $\begin{array}{l}\text { DPI, } \\
\text { calculations }\end{array}$ & 3499 & .493 & .500 & 0 & 1 \\
\hline
\end{tabular}


Table 5. Risk variables and economic shocks, FE.

Economic shocks are instrumented by natural disasters and terms of trade shocks

\begin{tabular}{l|cccc}
\hline & $\begin{array}{l}\text { Expropriation } \\
\text { risk, } t+1\end{array}$ & $\begin{array}{l}\text { Risk of } \\
\text { repudiation of } \\
\text { contracts, } t+1\end{array}$ & $\begin{array}{c}\text { Expropriation } \\
\text { risk, } t+1\end{array}$ & $\begin{array}{c}\text { Risk of } \\
\text { repudiation of } \\
\text { contracts, } t+1\end{array}$ \\
\hline & $(1)$ & $(2)$ & $(3)$ & $(4)$ \\
Economic shock in & OLS & OLS & IV & IV \\
years $t$, $t$-1, or t-2 & 0.0213 & 0.164 & $1.689^{*}$ & $1.769^{* *}$ \\
Log GDP pc, & {$[0.0897]$} & {$[0.100]$} & {$[0.879]$} & {$[0.792]$} \\
lagged 3 years & 0.526 & -0.0838 & -0.672 & $-1.446^{*}$ \\
Log (Population) & {$[0.574]$} & {$[0.715]$} & {$[0.712]$} & {$[0.814]$} \\
lagged 3 years & $-3.226^{* *}$ & $-3.713^{* * *}$ & $-3.848^{* * *}$ & $-4.487^{* * *}$ \\
Openness & {$[1.466]$} & {$[1.324]$} & {$[1.009]$} & {$[1.040]$} \\
lagged 3 years & $-0.0133^{* * *}$ & $-0.0127^{* * *}$ & $-0.00998^{* * *}$ & $-0.00995^{* * *}$ \\
Government spending, & {$[0.00353]$} & {$[0.00316]$} & {$[0.00345]$} & {$[0.00347]$} \\
\% of GDP, I. 3 years & $0.0376^{* *}$ & 0.0235 & 0.0140 & 0.000437 \\
Expropriation risk, & {$[0.0174]$} & {$[0.0172]$} & {$[0.0210]$} & {$[0.0182]$} \\
lagged 3 years & $0.168^{* * *}$ & & $0.172^{* * *}$ & \\
Risk of repudiation of & {$[0.0601]$} & & {$[0.0475]$} & \\
contracts, I. 3years & & $0.204^{* * *}$ & & $0.127^{* *}$ \\
Year fixed effects & & {$[0.0552]$} & & {$[0.0624]$} \\
Country fixed effects & Yes & Yes & Yes & Yes \\
Observations & 1,144 & 1,144 & 1,144 & Yes \\
\hline Number of countries & 114 & 114 & 114 & 1,144 \\
\hline Robust sta & & & 114 \\
\hline
\end{tabular}

Robust standard errors in brackets.

* significant at $10 \% ; * *$ significant at $5 \%$; *** significant at $1 \%$ 
Table 6. Risk variables and economic shocks, with interactions, FE Regimes are classified by Polity measure from Polity IV.

Economic shocks are instrumented by natural disasters and terms of trade shocks.

\begin{tabular}{|c|c|c|c|c|}
\hline & $\begin{array}{l}\text { Expropriation } \\
\text { risk, } t+1\end{array}$ & $\begin{array}{l}\text { Risk of } \\
\text { repudiation of } \\
\text { contracts, } t+1\end{array}$ & $\begin{array}{l}\text { Expropriation } \\
\text { risk, } t+1\end{array}$ & $\begin{array}{l}\text { Risk of } \\
\text { repudiation of } \\
\text { contracts, } t+1\end{array}$ \\
\hline & (1) & (2) & (3) & (4) \\
\hline & OLS & OLS & IV & IV \\
\hline \multirow[t]{2}{*}{ Shock*Autocracy } & 0.123 & $0.429 * *$ & 1.462 & 1.419 \\
\hline & {$[0.158]$} & {$[0.196]$} & [1.061] & [1.008] \\
\hline Shock*Intermediate & 0.184 & $0.352^{* *}$ & $2.983^{* *}$ & $1.846^{*}$ \\
\hline Regime & [0.177] & {$[0.176]$} & [1.418] & {$[1.020]$} \\
\hline \multirow[t]{2}{*}{ Shock ${ }^{*}$ Democracy } & 0.150 & $0.217^{*}$ & -0.741 & 0.0568 \\
\hline & {$[0.138]$} & [0.129] & [1.180] & {$[0.758]$} \\
\hline \multirow[t]{2}{*}{ Autocracy } & $0.651^{* * *}$ & 0.330 & -0.307 & -0.322 \\
\hline & [0.199] & [0.208] & [0.992] & {$[0.765]$} \\
\hline \multirow[t]{2}{*}{ Intermediate Regime } & 0.306 & 0.204 & $-1.437^{*}$ & -0.483 \\
\hline & {$[0.200]$} & [0.192] & {$[0.756]$} & {$[0.535]$} \\
\hline $\log G D P p c$ & $-0.492^{* * *}$ & $-0.716^{* * *}$ & -0.323 & -0.532 \\
\hline lagged 3 years & [0.0839] & {$[0.0921]$} & {$[0.864]$} & {$[0.766]$} \\
\hline Log (Population) & $-0.214^{* * *}$ & $-0.231^{* * *}$ & $-3.919^{* * *}$ & $-4.319^{* * *}$ \\
\hline lagged 3 years & [0.0529] & {$[0.0545]$} & [1.095] & [0.999] \\
\hline Openness & $-0.00991^{* * *}$ & $-0.00821^{* * *}$ & -0.00309 & -0.00666 \\
\hline lagged 3 years & [0.00204] & [0.00203] & [0.00508] & [0.00407] \\
\hline Government spending, & 0.00509 & 0.00969 & $0.0424^{* *}$ & 0.0246 \\
\hline$\%$ of GDP, I. 3 years & [0.00863] & {$[0.00921]$} & {$[0.0184]$} & {$[0.0154]$} \\
\hline Expropriation Risk, & $0.334^{* * *}$ & & $0.120 *$ & \\
\hline lagged 3 years & [0.0419] & & {$[0.0622]$} & \\
\hline Risk of repudiation of & & $0.366^{* * *}$ & & $0.142^{* * *}$ \\
\hline contracts, I. 3years & & {$[0.0382]$} & & {$[0.0509]$} \\
\hline Year fixed effects & Yes & Yes & Yes & Yes \\
\hline Country fixed effects & Yes & Yes & Yes & Yes \\
\hline Observations & 1,086 & 1,086 & 1,086 & 1,086 \\
\hline Number of countries & 109 & 109 & 109 & 109 \\
\hline
\end{tabular}

Robust standard errors in brackets. ${ }^{*}$ significant at $10 \% ; * *$ significant at $5 \%$; $* * *$ significant at $1 \%$ Note: cutoff points for democracies and autocracies are 7 and -7 , respectively. 
Table 7. Risk variables and economic shocks, with interactions, FE

Regimes are classified by Legislative Electoral Competitiveness Index from World Bank Database of Political Institutions of Beck et al. (2006)

Economic shocks are instrumented by natural disasters and terms of trade shocks.

\begin{tabular}{|c|c|c|c|c|}
\hline & $\begin{array}{l}\text { Expropriation } \\
\text { risk, } t+1\end{array}$ & $\begin{array}{l}\text { Risk of } \\
\text { repudiation of } \\
\text { contracts, } t+1\end{array}$ & $\begin{array}{l}\text { Expropriation } \\
\text { risk, } t+1\end{array}$ & $\begin{array}{l}\text { Risk of } \\
\text { repudiation of } \\
\text { contracts, } t+1\end{array}$ \\
\hline & (1) & (2) & (3) & (4) \\
\hline & OLS & OLS & IV & IV \\
\hline \multirow[t]{2}{*}{ Shock*Autocracy } & 0.198 & $0.332^{*}$ & 0.189 & 0.836 \\
\hline & {$[0.190]$} & [0.197] & [1.690] & [1.044] \\
\hline Shock*Intermediate & 0.102 & $0.260 *$ & 3.990 ** & $3.700 * *$ \\
\hline Regime & {$[0.164]$} & [0.139] & [1.719] & [1.524] \\
\hline \multirow[t]{2}{*}{ Shock*Democracy } & 0.124 & $0.294^{* *}$ & -3.882 & 0.211 \\
\hline & [0.113] & {$[0.120]$} & [3.367] & [1.953] \\
\hline \multirow[t]{2}{*}{ Autocracy } & $0.587^{* * *}$ & $0.443^{*}$ & -0.629 & 0.276 \\
\hline & {$[0.190]$} & {$[0.227]$} & [1.056] & [0.691] \\
\hline \multirow[t]{2}{*}{ Intermediate Regime } & $0.396^{* *}$ & $0.292^{*}$ & $-3.508^{*}$ & -1.779 \\
\hline & {$[0.185]$} & [0.163] & {$[1.839]$} & [1.316] \\
\hline $\log G D P p c$ & $-0.440 * * *$ & $-0.723^{* * *}$ & 1.527 & -1.186 \\
\hline lagged 3 years & {$[0.0821]$} & [0.0995] & [1.819] & [1.165] \\
\hline Log (Population) & $-0.187^{* * *}$ & $-0.204^{* * *}$ & $-4.792^{* * *}$ & $-5.360^{* * *}$ \\
\hline lagged 3 years & {$[0.0471]$} & {$[0.0539]$} & {$[1.708]$} & [1.249] \\
\hline Openness & $-0.00817^{* * *}$ & $-0.00803^{* * *}$ & $-0.0164^{* *}$ & $-0.0108^{* *}$ \\
\hline lagged 3 years & {$[0.00185]$} & {$[0.00185]$} & {$[0.00786]$} & {$[0.00531]$} \\
\hline Government spending, & -0.00864 & 0.00654 & $0.0431^{*}$ & $0.0310^{*}$ \\
\hline$\%$ of GDP, I. 3 years & {$[0.00790]$} & [0.00863] & {$[0.0241]$} & [0.0179] \\
\hline Expropriation Risk, & $0.369^{* * *}$ & & 0.0169 & \\
\hline lagged 3 years & [0.0369] & & {$[0.0885]$} & \\
\hline Risk of repudiation of & & $0.365^{\star * *}$ & & 0.0516 \\
\hline contracts, I. 3years & & {$[0.0381]$} & & {$[0.0745]$} \\
\hline Year fixed effects & Yes & Yes & Yes & Yes \\
\hline Country fixed effects & Yes & Yes & Yes & Yes \\
\hline Observations & 1,129 & 1,129 & 1,129 & 1,129 \\
\hline Number of countries & 111 & 111 & 111 & 111 \\
\hline
\end{tabular}

Robust standard errors in brackets. * significant at $10 \% ; * *$ significant at $5 \% ; * * *$ significant at $1 \%$

Note: cutoff points for democracies and autocracies are 7 and 3 , respectively. 
Table 8. Risk variables and economic shocks, with interactions, FE. Only periods with no changes of government are included.

Economic shocks are instrumented by natural disasters and terms of trade shocks

\begin{tabular}{|c|c|c|c|c|}
\hline & $\begin{array}{l}\text { Expropriation } \\
\text { risk, } t+1\end{array}$ & $\begin{array}{l}\text { Risk of } \\
\text { repudiation of } \\
\text { contracts, } t+1\end{array}$ & $\begin{array}{l}\text { Expropriation } \\
\text { risk, } t+1\end{array}$ & $\begin{array}{l}\text { Risk of } \\
\text { repudiation of } \\
\text { contracts, } t+1\end{array}$ \\
\hline & (1) & (2) & (3) & (4) \\
\hline & OLS & OLS & IV & IV \\
\hline \multirow[t]{2}{*}{ Shock*Autocracy } & 0.0518 & 0.307 & 1.214 & 1.111 \\
\hline & [0.154] & [0.264] & [1.023] & [0.946] \\
\hline Shock*Intermediate & 0.282 & 0.215 & $3.095^{* * *}$ & $2.575^{\star * \star}$ \\
\hline Regime & [0.202] & [0.213] & [1.002] & {$[0.859]$} \\
\hline \multirow[t]{2}{*}{ Shock ${ }^{*}$ Democracy } & 0.252 & 0.222 & 6.181 & 4.394 \\
\hline & [0.224] & [0.169] & [4.613] & [3.895] \\
\hline \multirow[t]{2}{*}{ Autocracy } & 0.166 & -0.0198 & 3.392 & 2.144 \\
\hline & [0.480] & [0.461] & [2.617] & [2.216] \\
\hline \multirow[t]{2}{*}{ Intermediate Regime } & -0.477 & -0.0862 & 1.348 & 0.970 \\
\hline & [0.394] & {$[0.356]$} & [2.340] & [1.966] \\
\hline $\log G D P p c$ & 0.433 & 0.401 & -2.446 & -1.907 \\
\hline lagged 3 years & [0.712] & [0.840] & [1.638] & [1.512] \\
\hline Log (Population) & -1.803 & -3.056 & -4.183 & $-5.428^{* *}$ \\
\hline lagged 3 years & [1.775] & [1.843] & [2.820] & [2.380] \\
\hline Openness & $-0.0105^{* *}$ & $-0.0120^{* * *}$ & 0.00275 & -0.00373 \\
\hline lagged 3 years & {$[0.00474]$} & {$[0.00456]$} & {$[0.00760]$} & [0.00594] \\
\hline Government spending, & $0.0541^{* *}$ & 0.0269 & 0.0208 & 0.00967 \\
\hline$\%$ of GDP, I. 3 years & {$[0.0233]$} & {$[0.0217]$} & {$[0.0346]$} & {$[0.0279]$} \\
\hline Expropriation Risk, & $0.202^{\star *}$ & & $0.373^{* *}$ & \\
\hline lagged 3 years & [0.0826] & & {$[0.150]$} & \\
\hline Risk of repudiation of & & $0.258^{* * *}$ & & $0.238^{* *}$ \\
\hline contracts, I. 3years & & {$[0.0855]$} & & {$[0.0960]$} \\
\hline Year fixed effects & Yes & Yes & Yes & Yes \\
\hline Country fixed effects & Yes & Yes & Yes & Yes \\
\hline Observations & 629 & 629 & 629 & 629 \\
\hline Number of countries & 101 & 101 & 101 & 101 \\
\hline
\end{tabular}

Robust standard errors in brackets.

* significant at $10 \%$;* significant at $5 \%$; *** significant at $1 \%$ 
Table 9. Risk variables and economic shocks, with interactions, FE. Different endpoints (robustness check). Only periods with no changes of government are included. Economic shocks are instrumented by natural disasters and terms of trade shocks

\begin{tabular}{|c|c|c|c|c|c|c|c|c|}
\hline & $\begin{array}{l}\text { Expropriation } \\
\text { risk, } t+1\end{array}$ & $\begin{array}{l}\text { Risk of } \\
\text { repudiation of } \\
\text { contracts, } t+1\end{array}$ & $\begin{array}{l}\text { Expropriation } \\
\text { risk, } t+1\end{array}$ & $\begin{array}{l}\text { Risk of } \\
\text { repudiation of } \\
\text { contracts, } t+1\end{array}$ & $\begin{array}{l}\text { Expropriation } \\
\text { risk, } t+1\end{array}$ & $\begin{array}{l}\text { Risk of } \\
\text { repudiation of } \\
\text { contracts, } t+1\end{array}$ & $\begin{array}{l}\text { Expropriation } \\
\text { risk, } t+1\end{array}$ & $\begin{array}{l}\text { Risk of } \\
\text { repudiation of } \\
\text { contracts, } t+1\end{array}$ \\
\hline & \multicolumn{2}{|c|}{ Polity endpoints -7 and 6} & \multicolumn{2}{|c|}{ Polity endpoints are -7 and 8} & \multicolumn{2}{|c|}{ Polity endpoints are -6 and 7} & \multicolumn{2}{|c|}{ Polity endpoints are -8 and 7} \\
\hline & (1) & (2) & (3) & (4) & (5) & (6) & (7) & (8) \\
\hline \multirow[t]{2}{*}{ Shock*Autocracy } & 1.424 & 1.061 & $1.832^{*}$ & 1.485 & $1.947^{* *}$ & $1.747^{* *}$ & -0.693 & -2.013 \\
\hline & {$[1.000]$} & [1.047] & {$[1.027]$} & [0.952] & {$[0.961]$} & {$[0.860]$} & [1.013] & [1.243] \\
\hline Shock*Intermediate & $3.172^{* * *}$ & $2.963^{* * *}$ & $3.120^{* * *}$ & $2.922^{* * *}$ & $2.461^{* *}$ & $1.801^{* *}$ & $4.700^{* *}$ & $5.011^{* *}$ \\
\hline Regime & [1.068] & {$[0.916]$} & {$[1.087]$} & {$[0.950]$} & {$[1.020]$} & {$[0.862]$} & {$[2.290]$} & [2.313] \\
\hline \multirow[t]{2}{*}{ Shock ${ }^{*}$ Democracy } & $4.490 *$ & 1.987 & 4.671 & 1.120 & 6.470 & 4.308 & 6.998 & 5.997 \\
\hline & [2.409] & [1.997] & {$[5.506]$} & [3.568] & [4.705] & [3.739] & [5.401] & [5.447] \\
\hline \multirow[t]{2}{*}{ Autocracy } & $2.546^{\star *}$ & 0.991 & 2.598 & 0.837 & 2.844 & 1.660 & $6.269^{*}$ & $7.183^{*}$ \\
\hline & {$[1.220]$} & {$[1.096]$} & [2.333] & [1.438] & {$[2.561]$} & [2.010] & [3.624] & [3.738] \\
\hline \multirow[t]{2}{*}{ Intermediate Regime } & 0.665 & -0.286 & 1.003 & -0.153 & 1.678 & 1.134 & 1.832 & 1.291 \\
\hline & [1.106] & [0.973] & {$[2.476]$} & [1.703] & [2.419] & [1.933] & {$[2.856]$} & [2.822] \\
\hline $\log G D P p c$ & $-1.992^{*}$ & -1.382 & -1.857 & -1.345 & -2.378 & -1.745 & -3.497 & -3.617 \\
\hline lagged 3 years & {$[1.061]$} & [1.047] & [1.200] & [1.080] & {$[1.651]$} & [1.456] & [2.363] & [2.490] \\
\hline Log (Population) & $-4.439^{*}$ & $-5.291^{* * *}$ & -3.559 & $-5.866^{\star * *}$ & -3.690 & $-4.641^{* *}$ & -6.083 & -7.900 ** \\
\hline lagged 3 years & [2.299] & {$[1.862]$} & [2.839] & [1.967] & [2.937] & {$[2.341]$} & [3.836] & [3.837] \\
\hline Openness & 0.00314 & -0.00533 & 0.00330 & -0.00496 & 0.00311 & -0.00356 & 0.00826 & 0.00472 \\
\hline lagged 3 years & [0.00632] & {$[0.00532]$} & {$[0.00850]$} & {$[0.00585]$} & {$[0.00747]$} & {$[0.00553]$} & {$[0.0110]$} & {$[0.0102]$} \\
\hline Government spending, & 0.0227 & 0.0146 & 0.0274 & 0.0104 & 0.0162 & 0.00597 & 0.0244 & 0.0181 \\
\hline$\%$ of GDP, I. 3 years & {$[0.0295]$} & {$[0.0228]$} & [0.0283] & [0.0240] & {$[0.0360]$} & [0.0275] & {$[0.0422]$} & {$[0.0397]$} \\
\hline Expropriation Risk, & $0.333^{* * *}$ & & $0.356^{*}$ & & $0.359 * *$ & & $0.407^{* *}$ & \\
\hline lagged 3 years & {$[0.100]$} & & [0.198] & & {$[0.148]$} & & {$[0.177]$} & \\
\hline Risk of repudiation of & & $0.223^{* * *}$ & & $0.193^{* *}$ & & $0.239^{* * *}$ & & $0.316^{* *}$ \\
\hline contracts, I. 3years & & {$[0.0771]$} & & {$[0.0822]$} & & {$[0.0887]$} & & [0.122] \\
\hline Year fixed effects & Yes & Yes & Yes & Yes & Yes & Yes & Yes & Yes \\
\hline Country fixed effects & Yes & Yes & Yes & Yes & Yes & Yes & Yes & Yes \\
\hline Observations & 629 & 629 & 629 & 629 & 629 & 629 & 629 & 629 \\
\hline Number of countries & 101 & 101 & 101 & 101 & 101 & 101 & 101 & 101 \\
\hline
\end{tabular}

Robust standard errors in brackets. All specifications are IV estimates of equation (2).

* significant at $10 \% ; * *$ significant at $5 \% ; * * *$ significant at $1 \%$ 
APPENDIX (This appendix might be web-based or dropped altogether with a reference to a working paper version of this paper!)

Proof. [Lemma 1] Consider a subgame at $t=2$ if a new government comes to power. For any government from the pool of possible governments, the prior probability that a government has high competence is $\mu$. As we are looking for the equilibrium in pure strategies, the government's strategy $\operatorname{Pr}(x \mid \theta, t=2)$ can be written as $x_{\theta 2} \in\{0,1\}$, where $\theta$ is the type of the government.

The outcome $y=1$ is possible if: (1) competence $\theta=\theta_{H}$, and predation $x=1,(2)$ competence $\theta=\theta_{H}$, and predation $x=0$, (3) competence $\theta=\theta_{L}$, and predation $x=0$. The outcome $y=0$ is possible in the following cases: (1) competence $\theta=\theta_{H}$, and predation $x=1,(2)$ competence $\theta=\theta_{L}$, and predation $x=0,(3)$ competence $\theta=\theta_{L}$, and predation $x=1$. Probabilities of these outcomes depend on people's prior beliefs about the types of a government and on the government's strategy. People's posterior beliefs about the government's competence are computed by Bayesian formula:

$$
\begin{gathered}
\left.\widehat{\mu_{2}}\right|_{y=1}=\frac{\mu * x_{H 2} * p_{H}+\mu *\left(1-x_{H 2}\right)}{\mu * x_{H 2} * p_{H}+\mu *\left(1-x_{H 2}\right)+(1-\mu) *\left(1-x_{L 2}\right) * p_{L}} \\
\left.\widehat{\mu_{2}}\right|_{y=0}=\frac{\mu * x_{H 2} *\left(1-p_{H}\right)}{\mu * x_{H 2} *\left(1-p_{H}\right)+(1-\mu) *\left(1-x_{L}\right) *\left(1-p_{L}\right)+(1-\mu) * x_{L 2}}
\end{gathered}
$$

Now consider four possible pure strategy profiles of a government at $t=2: x_{H 2}=1, x_{L 2}=1 ; x_{H 2}=1, x_{L 2}=0$; $x_{H 2}=0, x_{L 2}=1 ; x_{H 2}=0, x_{L 2}=0$. The rest of the proof is organized as follows. First, for each strategy of a government, we find people's best response to this strategy. Second, we check if the original strategy profile of a government is still a best response to people's strategy, i.e. if a proposed pair of strategies constitute an equilibrium in this game.

Note that everywhere it is optimal for people to change the government if their posterior that the government has high competence is lower than $\mu^{*}(\gamma)=\mu-\frac{c(\gamma)}{\gamma \delta p_{H}[f(1)-f(0)]}$. Similarly, it is optimal to keep the government if people's posterior that the government has high competence is higher than $\mu^{*}(\gamma)$. Indeed, as in the third period when every type of government will predate the citizens compare $\delta\left(\widehat{\mu_{2}}\left(p_{H} f(1)+\left(1-p_{H}\right) f(0)\right)+\left(1-\widehat{\mu_{2}}\right) f(0)\right)$ and $-c(\gamma)+\delta\left(\gamma\left[\mu\left(p_{H} f(1)+\left(1-p_{H}\right) f(0)\right)+(1-\mu) f(0)\right]+(1-\gamma)\left[\widehat{\mu_{2}}\left(p_{H} f(1)+\left(1-p_{H}\right) f(0)\right)+\left(1-\widehat{\mu_{2}}\right) f(0)\right]\right)$. It is optimal for the people to overthrow the current government if $\left(\widehat{\mu_{2}}-\mu\right)\left(p_{H} f(1)-p_{H} f(0)\right)<-\frac{c(\gamma)}{\gamma \delta}$.

For a new government in the second period: 
(1) Assume that $x_{H 2}=1, x_{L 2}=1$. People's posteriors about the government's competence are $\left.\widehat{\mu_{2}}\right|_{y=1}=$ $\frac{\mu * p_{H}}{\mu * p_{H}}=1>\mu^{*}(\gamma),\left.\widehat{\mu_{2}}\right|_{y=0}=\frac{\mu *\left(1-p_{H}\right)}{\mu *\left(1-p_{H}\right)+(1-\mu)}=\frac{\mu *\left(1-p_{H}\right)}{-\mu p_{H}+1}<\mu^{*}(\gamma)$ if $\frac{c(\gamma)}{\gamma \delta p_{H}[f(1)-f(0)]}<\frac{\mu p_{H}(1-\mu)}{1-\mu p_{H}}($ i.e. $\quad c(\gamma)<$ $\left.\frac{\gamma \delta \mu p_{H}^{2}(1-\mu)}{1-\mu p_{H}}[f(1)-f(0)]\right)$. Therefore, the optimal response of people to the assumed government's strategy is $s_{2} \mid 1=$ not overthrow, $s_{2} \mid 0=$ overthrow.

The payoffs of different types of the government given the people's strategy are following. For $\theta=\theta_{H}$, the payoff from predation is $U\left(\theta_{H} \mid x=1\right)=B+R+\delta\left(p_{H}(B+R)+\left(1-p_{H}\right)(1-\gamma)(B+R)\right)$, and the payoff from restraint is $U\left(\theta_{H} \mid x=0\right)=B+\delta(B+R)$. So, for a high-competent government, predation is profitable if $R>\delta \gamma\left(1-p_{H}\right)(B+R)$. Similarly, for $\theta=\theta_{L}$, the payoff from predation is $U\left(\theta_{L} \mid x=1\right)=B+R+\delta(1-\gamma)(B+R)$, and the payoff from restraint is $U\left(\theta_{L} \mid x=0\right)=B+\delta\left(p_{L}(B+R)+\left(1-p_{L}\right)(1-\gamma)(B+R)\right)$. Therefore, a low-competent government predates if $R>\delta \gamma p_{L}(B+R)$. For $1-p_{H}>p_{L}$, strategy profiles $x_{H 2}=1, x_{L 2}=1$, and $s_{2} \mid 1=$ not overthrow, $s_{2} \mid 0=$ overthrow constitute equilibrium if $R>\delta \gamma\left(1-p_{H}\right)(B+R)$.

(2) Assume that $x_{H 2}=1, x_{L 2}=0$. Then $\left.\widehat{\mu_{2}}\right|_{y=1}=\frac{\mu * p_{H}}{\mu * p_{H}+(1-\mu) * p_{L}}=\frac{\mu}{\mu+(1-\mu) * \frac{p_{L}}{p_{H}}}>\mu>\mu^{*}(\gamma),\left.\widehat{\mu_{2}}\right|_{y=0}=$ $\frac{\mu *\left(1-p_{H}\right)}{\mu *\left(1-p_{H}\right)+(1-\mu) *\left(1-p_{L}\right)}=\frac{\mu}{\mu+(1-\mu) * \frac{1-p_{L}}{1-p_{H}}}<\mu$. We used the fact that $p_{L}<p_{H}$ by the assumption. Therefore, the optimal response of people to the assumed government's strategy is $s_{2} \mid 1=$ not overthrow and $s_{2} \mid 0=$ overthrow if $\left.\widehat{\mu_{2}}\right|_{y=0}<\mu^{*}(\gamma), s_{2} \mid 0=$ not overthrow if $\left.\widehat{\mu_{2}}\right|_{y=0}>\mu^{*}(\gamma)$. As for the people's strategy $s_{2} \mid 1=$ not overthrow and $s_{2} \mid 0=$ not overthrow the optimal response for both types of government is to predate, $s_{2} \mid 1=$ not overthrow and $s_{2} \mid 0=$ not overthrow is not an equilibrium strategy. The strategy $s_{2} \mid 1=$ not overthrow, $s_{2} \mid 0=$ overthrow is optimal for the citizens if $\frac{\mu}{\mu+(1-\mu) * \frac{1-p_{L}}{1-p_{H}}}<\mu^{*}(\gamma)$ (i.e. $\left.c(\gamma)<\gamma \delta p_{H} \cdot\left(\mu-\frac{\mu}{\mu+(1-\mu) * \frac{1-p_{L}}{1-p_{H}}}\right) \cdot[f(1)-f(0)]\right)$.

For a high-competent government, predation is profitable if $R>\delta \gamma\left(1-p_{H}\right)(B+R)$. Similarly, a low-competent government predates if $R>\delta \gamma p_{L}(B+R)$. As $1-p_{H}>p_{L}$, strategy $x_{L 2}=0$ is not optimal for a low-type government, and for any parameter values $x_{H 2}=1, x_{L 2}=0$ is not the part of an equilibrium.

(3) Assume that $x_{H 2}=0, x_{L 2}=1$. Then $\left.\widehat{\mu_{2}}\right|_{y=1}=1>\mu^{*}(\gamma),\left.\widehat{\mu_{2}}\right|_{y=0}=0<\mu^{*}(\gamma)$. Therefore, the optimal response of people to the assumed government's strategy is $s_{2} \mid 1=$ not overthrow, $s_{2} \mid 0=$ overthrow. As before, for a high-competent government, predation is profitable if $R>\gamma \delta\left(1-p_{H}\right)(B+R)$. Similarly, for $\theta=\theta_{L}$, predation is optimal if $R>\delta \gamma p_{L}(B+R)$. As a result, strategy profiles $x_{H 2}=0, x_{L 2}=1$, and $s_{2} \mid 1=$ not overthrow, $s_{2} \mid 0=$ overthrow constitute equilibrium if $\gamma \delta p_{L}(B+R)<R<\gamma \delta\left(1-p_{H}\right)(B+R)$.

(4) Assume that $x_{H 2}=0, x_{L 2}=0$. Then $\left.\widehat{\mu_{2}}\right|_{y=1}=\frac{\mu}{\mu+(1-\mu) * p_{L}}>\mu>\mu^{*}(\gamma),\left.\widehat{\mu_{2}}\right|_{y=0}=0<\mu^{*}(\gamma)$. As a result, the strategy profiles $x_{H 2}=0, x_{L 2}=0$, and $s_{2} \mid 1=$ not overthrow, $s_{2} \mid 0=$ overthrow constitute an equilibrium if $\gamma \delta p_{L}(B+R)>R$. 
For an old government, after the first period, the people's posterior beliefs that the government has high competence depend on the government strategy in the first period. Similar to the case of a new government in the second period, these beliefs can be computed by Bayesian updating:

$$
\begin{gathered}
\left.\widehat{\mu_{1}}\right|_{y_{1}=1}=\frac{\mu * x_{H 1} * p_{H}+\mu *\left(1-x_{H 1}\right)}{\mu * x_{H 1} * p_{H}+\mu *\left(1-x_{H 1}\right)+(1-\mu) *\left(1-x_{L 1}\right) * p_{L}} \\
\left.\widehat{\mu_{1}}\right|_{y_{1}=0}=\frac{\mu * x_{H 1} *\left(1-p_{H}\right)}{\mu * x_{H 1} *\left(1-p_{H}\right)+(1-\mu) *\left(1-x_{L 1}\right) *\left(1-p_{L}\right)+(1-\mu) * x_{L 1}}
\end{gathered}
$$

- For $x_{H 1}=1, x_{L 1}=1$, these beliefs are $\left.\widehat{\mu_{1}}\right|_{y_{1}=1}=1>\mu^{*}(\gamma)$ and $\left.\widehat{\mu_{1}}\right|_{y_{1}=0}=\frac{\mu *\left(1-p_{H}\right)}{\mu *\left(1-p_{H}\right)+(1-\mu)}<\mu^{*}(\gamma)$.

- For $x_{H 1}=1, x_{L 1}=0$, these beliefs are $\left.\widehat{\mu_{1}}\right|_{y_{1}=1}=\frac{\mu * p_{H}}{\mu * p_{H}+(1-\mu) * p_{L}}=\frac{\mu}{\mu+(1-\mu) * \frac{p_{L}}{p_{H}}}>\mu>\mu^{*}(\gamma)$ and $\left.\widehat{\mu_{1}}\right|_{y_{1}=0}=$ $\frac{\mu *\left(1-p_{H}\right)}{\mu *\left(1-p_{H}\right)+(1-\mu) *\left(1-p_{L}\right)}=\frac{\mu}{\mu+(1-\mu) * \frac{1-p_{L}}{1-p_{H}}}<\mu$.

- For $x_{H 1}=0, x_{L 1}=1$, these beliefs are $\left.\widehat{\mu_{1}}\right|_{y_{1}=1}=1>\mu^{*}(\gamma)$ and $\left.\widehat{\mu_{1}}\right|_{y_{1}=0}=0<\mu^{*}(\gamma)$.

- For $x_{H 1}=0, x_{L 1}=0$, these beliefs are $\left.\widehat{\mu_{1}}\right|_{y_{1}=1}=\frac{\mu}{\mu+(1-\mu) * p_{L}}>\mu>\mu^{*}(\gamma)$, and $\left.\widehat{\mu_{1}}\right|_{y_{1}=0}=0<\mu^{*}(\gamma)$.

Now, we look separately at the cases of $y=0$ and $y=1$ and check which equilibria might be supported for different strategies of the government in the first period. Denote $\left.\widehat{\mu_{2}}\right|_{y_{2}=i}(a, b)$ as the posterior belief of the citizens that the government is high-competent after $y_{2}=i$ if the government's strategy is $x_{H 2}=a$ and $x_{L 2}=b$.

1. Assume that $y=0, x_{H 1}=1$, and $x_{L 1}=1$. Here $\left.\widehat{\mu_{1}}\right|_{y_{1}=0}=\frac{\mu *\left(1-p_{H}\right)}{1-\mu p_{H}}<\mu^{*}(\gamma)$. Equilibria in a continuation game are as described above because $\left.\widehat{\mu_{2}}\right|_{y_{2}=1}(1,1)=1>\mu^{*}(\gamma)$ and $\left.\widehat{\mu_{2}}\right|_{y_{2}=0}(1,1)=\frac{\widehat{\mu_{1}} *\left(1-p_{H}\right)}{-\widehat{\mu_{1} p_{H}+1}<}$ $\left.\widehat{\mu_{1}}\right|_{y_{1}=0}<\mu^{*}(\gamma) ;\left.\widehat{\mu_{2}}\right|_{y_{2}=1}(1,0)=\frac{\widehat{\mu_{1}}}{\widehat{\mu_{1}}+\left(1-\widehat{\mu_{1}}\right) * \frac{p_{L}}{p_{H}}}=\frac{\mu}{\mu+(1-\mu) * \frac{p_{L}}{p_{H}\left(1-p_{H}\right)}}<\mu\left(\right.$ if $\left.\frac{p_{L}}{p_{H}\left(1-p_{H}\right)}>1\right)$ and $\left.\widehat{\mu_{2}}\right|_{y_{2}=0}(1,0)=$ $\frac{\widehat{\mu_{1}}}{\widehat{\mu_{1}}+\left(1-\widehat{\mu_{1}}\right) * \frac{1-p_{L}}{1-p_{H}}}<\left.\widehat{\mu_{1}}\right|_{y_{1}=0}<\mu$ (but $x_{H 2}=1, x_{L 2}=0$ do not constitute an equilibrium in a continuation game); $\left.\widehat{\mu_{2}}\right|_{y_{2}=1}(0,1)=1>\mu^{*}(\gamma)$ and $\left.\widehat{\mu_{2}}\right|_{y_{2}=0}(0,1)=0<\mu^{*}(\gamma) ;\left.\widehat{\mu_{2}}\right|_{y_{2}=1}(0,0)=\frac{\widehat{\mu_{1}}}{\widehat{\mu_{1}}+\left(1-\widehat{\mu_{1}}\right) * p_{L}}>\mu>\mu^{*}(\gamma)$ and $\left.\widehat{\mu_{2}}\right|_{y_{2}=0}=0<\mu^{*}(\gamma)$.

2. Assume that $y=0, x_{H 1}=1$, and $x_{L 1}=0$. Here $\left.\widehat{\mu_{1}}\right|_{y_{1}=0}=\frac{\mu}{\mu+(1-\mu) * \frac{1-p_{L}}{1-p_{H}}}<\mu$. Equilibria in a continuation game are as described above because $\left.\widehat{\mu_{2}}\right|_{y_{2}=1}(1,1)=1>\mu^{*}(\gamma)$ and $\left.\widehat{\mu_{2}}\right|_{y_{2}=0}(1,1)=\frac{\widehat{\mu_{1}} *\left(1-p_{H}\right)}{-\widehat{\mu_{1}} p_{H}+1}<\frac{\mu *\left(1-p_{H}\right)}{-\mu p_{H}+1}<$ $\mu^{*}(\gamma) ;\left.\widehat{\mu_{2}}\right|_{y_{2}=1}(1,0)=\frac{\widehat{\mu_{1}}}{\widehat{\mu_{1}}+\left(1-\widehat{\mu_{1}}\right) * \frac{p_{L}}{p_{H}}}=\frac{\mu}{\mu+(1-\mu) * \frac{p_{L}\left(1-p_{L}\right)}{p_{H}\left(1-p_{H}\right)}}>\mu>\mu^{*}(\gamma)$ and $\left.\widehat{\mu_{2}}\right|_{y_{2}=0}(1,0)=\frac{\widehat{\mu_{1}}}{\widehat{\mu_{1}}+\left(1-\widehat{\mu_{1}}\right) * \frac{1-p_{L}}{1-p_{H}}<}<$ $\left.\widehat{\mu_{1}}\right|_{y_{1}=0}<\mu$ (but $x_{H 2}=1, x_{L 2}=0$ do not constitute an equilibrium in a continuation game); $\left.\widehat{\mu_{2}}\right|_{y_{2}=1}(0,1)=$ $1>\mu^{*}(\gamma)$ and $\left.\widehat{\mu_{2}}\right|_{y_{2}=0}(0,1)=0<\mu^{*}(\gamma) ;\left.\widehat{\mu_{2}}\right|_{y_{2}=1}(0,0)=\frac{\widehat{\mu_{1}}}{\widehat{\mu_{1}}+\left(1-\widehat{\mu_{1}}\right) * p_{L}}=\frac{\mu}{\mu+(1-\mu) \frac{p_{L}\left(1-p_{L}\right)}{\left(1-p_{H}\right)}}>\mu^{*}(\gamma)$ and $\left.\widehat{\mu_{2}}\right|_{y_{2}=0}(0,0)=0<\mu^{*}(\gamma)$. 
3. Assume that $y=0, x_{H 1}=0$, and $x_{L 1}=1$. Here $\left.\widehat{\mu_{1}}\right|_{y_{1}=0}=0<\mu^{*}(\gamma)$. For any strategy of the government in the second period, posterior beliefs about the government's competence are $\left.\widehat{\mu_{2}}\right|_{y_{2}=1}=0$ and $\left.\widehat{\mu_{2}}\right|_{y_{2}=0}=0$. Therefore, the optimal strategy for people is $s_{2}\left|1=s_{2}\right| 0=$ overthrow, and $x_{H 2}=1$, and $x_{L 2}=1$ is the government's optimal response to that. So, the strategies $s_{2}\left|1=s_{2}\right| 0=$ overthrow, $x_{H 2}=1$, and $x_{L 2}=1$ constitute equilibrium in this continuation game, which is not a part of the described equilibrium.

4. Assume that $y=0, x_{H 1}=0$, and $x_{L 1}=0$. Here $\left.\widehat{\mu_{1}}\right|_{y_{1}=0}=0<\mu^{*}(\gamma)$. For any strategy of the government in the second period, posterior beliefs about the government's competence are $\left.\widehat{\mu_{2}}\right|_{y_{2}=1}=0$ and $\left.\widehat{\mu_{2}}\right|_{y_{2}=0}=0$. Therefore, the optimal strategy for people is $s_{2}\left|1=s_{2}\right| 0=$ overthrow, and $x_{H 2}=1$, and $x_{L 2}=1$ is the government's optimal response to that. So, the strategies $s_{2}\left|1=s_{2}\right| 0=$ overthrow, $x_{H 2}=1$, and $x_{L 2}=1$ constitute equilibrium in this continuation game, which is not a part of the described equilibrium.

5. Assume that $y=1, x_{H 1}=1$, and $x_{L 1}=1$. Here $\left.\widehat{\mu_{1}}\right|_{y_{1}=1}=1>\mu^{*}(\gamma)$. For any strategy of the government in the second period, posterior beliefs about the government's competence are $\left.\widehat{\mu_{2}}\right|_{y_{2}=1}=1$ and $\left.\widehat{\mu_{2}}\right|_{y_{2}=0}=1$. Therefore, the optimal strategy for people is $s_{2}\left|1=s_{2}\right| 0=$ not overthrow, and $x_{H 2}=1$, and $x_{L 2}=1$ is the government's optimal response to that. So, the strategies $s_{2}\left|1=s_{2}\right| 0=$ not overthrow, $x_{H 2}=1$, and $x_{L 2}=1$ constitute equilibrium in this continuation game, which is not a part of the described equilibrium.

6. Assume that $y=1, x_{H 1}=1$, and $x_{L 1}=0$. Here $\left.\widehat{\mu_{1}}\right|_{y_{1}=1}=\frac{\mu}{\mu+(1-\mu) * \frac{p_{L}}{p_{H}}}>\mu>\mu^{*}(\gamma)$. Equilibria in a continuation game are as described above because $\left.\widehat{\mu_{2}}\right|_{y_{2}=1}(1,1)=1>\mu^{*}(\gamma)$ and $\left.\widehat{\mu_{2}}\right|_{y_{2}=0}(1,1)=$ $\frac{\widehat{\mu_{1}} *\left(1-p_{H}\right)}{1-\widehat{\mu_{1} p_{H}}}=\frac{\mu}{\mu+(1-\mu) * \frac{p_{L}}{p_{H}\left(1-p_{H}\right)}}<\mu$ (if $\frac{p_{L}}{p_{H}\left(1-p_{H}\right)}>1$ ) and $\frac{\mu}{\mu+(1-\mu) * \frac{p_{L}}{p_{H}\left(1-p_{H}\right)}}<\mu^{*}(\gamma)$ if $c(\gamma)<\gamma \delta p_{H}$. $\left.\left(\mu-\frac{\mu}{\mu+(1-\mu) * \frac{p_{L}}{p_{H}\left(1-p_{H}\right)}}\right) \cdot[f(1)-f(0)]\right) ;\left.\widehat{\mu_{2}}\right|_{y_{2}=1}(1,0)=\frac{\widehat{\mu_{1}}}{\widehat{\mu_{1}}+\left(1-\widehat{\mu_{1}}\right) * \frac{p_{L}}{p_{H}}}>\left.\widehat{\mu_{1}}\right|_{y_{1}=1}>\mu^{*}(\gamma)$ and $\left.\widehat{\mu_{2}}\right|_{y_{2}=0}(1,0)=$ $\frac{\widehat{\mu_{1}}}{\widehat{\mu_{1}}+\left(1-\widehat{\mu_{1}}\right) * \frac{1-p_{L}}{1-p_{H}}}=\frac{\mu}{\mu+(1-\mu) * \frac{p_{L}}{p_{H}} * \frac{1-p_{L}}{1-p_{H}}}>\mu>\mu^{*}(\gamma)$ (but $x_{H 2}=1, x_{L 2}=0$ do not constitute an equilibrium in a continuation game); $\left.\widehat{\mu_{2}}\right|_{y_{2}=1}(0,1)=1>\mu^{*}(\gamma)$ and $\left.\widehat{\mu_{2}}\right|_{y_{2}=0}(0,1)=0<\mu^{*}(\gamma) ;\left.\widehat{\mu_{2}}\right|_{y_{2}=1}(0,0)=\frac{\widehat{\mu_{1}}}{\widehat{\mu_{1}}+\left(1-\widehat{\mu_{1}}\right) * p_{L}}>$ $\widehat{\mu_{1}}>\mu^{*}(\gamma)$ and $\left.\widehat{\mu_{2}}\right|_{y_{2}=0}(0,0)=0<\mu^{*}(\gamma)$.

7. Assume that $y=1, x_{H 1}=0$, and $x_{L 1}=1$. Here $\left.\widehat{\mu_{1}}\right|_{y_{1}=1}=1>\mu^{*}(\gamma)$. For any strategy of the government in the second period, posterior beliefs about the government's competence are $\left.\widehat{\mu_{2}}\right|_{y_{2}=1}=1$ and $\left.\widehat{\mu_{2}}\right|_{y_{2}=0}=1$. Therefore, the optimal strategy for people is $s_{2}\left|1=s_{2}\right| 0=$ not overthrow, and $x_{H 2}=1$, and $x_{L 2}=1$ is the government's optimal response to that. So, the strategies $s_{2}\left|1=s_{2}\right| 0=$ not overthrow, $x_{H 2}=1$, and $x_{L 2}=1$ constitute equilibrium in this continuation game, which is not a part of the described equilibrium. 
8. Assume that $y=1, x_{H 1}=0$, and $x_{L 1}=0$. Here $\left.\widehat{\mu_{1}}\right|_{y_{1}=1}=\frac{\mu}{\mu+(1-\mu) * p_{L}}>\mu>\mu^{*}(\gamma)$. If $x_{H 2}=1$ and $x_{L 2}=1$ then $\left.\widehat{\mu_{2}}\right|_{y_{2}=1}=1>\mu^{*}(\gamma)$ and $\left.\widehat{\mu_{2}}\right|_{y_{2}=0}=\frac{\widehat{\mu_{1}} *\left(1-p_{H}\right)}{-\widehat{\mu_{1} p_{H}+1}}=\frac{\mu}{\mu+(1-\mu) * \frac{p_{L}}{\left(1-p_{H}\right)}}>\mu>\mu^{*}(\gamma)$. Then strategies $x_{H 2}=1$, and $x_{L 2}=1$, and $s_{2}\left|1=s_{2}\right| 0=$ not overthrow constitute an equilibrium in a continuation game. In other cases, equilibria in a continuation game are as described above because $\left.\widehat{\mu_{2}}\right|_{y_{2}=1}(1,0)=$ $\frac{\widehat{\mu_{1}}}{\widehat{\mu_{1}}+\left(1-\widehat{\mu_{1}}\right) * \frac{p_{L}}{p_{H}}}>\left.\widehat{\mu_{1}}\right|_{y_{1}=1}>\mu^{*}(\gamma)$ and $\left.\widehat{\mu_{2}}\right|_{y_{2}=0}(1,0)=\frac{\widehat{\mu_{1}}}{\widehat{\mu_{1}}+\left(1-\widehat{\mu_{1}}\right) * \frac{1-p_{L}}{1-p_{H}}}=\frac{\mu}{\mu+(1-\mu) * \frac{p_{L}\left(1-p_{L}\right)}{1-p_{H}}}>\mu>\mu^{*}(\gamma)(\mathrm{but}$ $x_{H 2}=1, x_{L 2}=0$ do not constitute an equilibrium in a continuation game); $\left.\widehat{\mu_{2}}\right|_{y_{2}=1}(0,1)=1>\mu^{*}(\gamma)$ and $\left.\widehat{\mu_{2}}\right|_{y_{2}=0}(0,1)=0<\mu^{*}(\gamma) ;\left.\widehat{\mu_{2}}\right|_{y_{2}=1}(0,0)=\frac{\widehat{\mu_{1}}}{\widehat{\mu_{1}}+\left(1-\widehat{\mu_{1}}\right) * p_{L}}>\left.\widehat{\mu_{1}}\right|_{y_{1}=1}>\mu^{*}(\gamma)$ and $\left.\widehat{\mu_{2}}\right|_{y_{2}=0}(0,0)=0<\mu^{*}(\gamma)$.

Proof. [Proposition 1] We consider the case of the following equilibrium in a continuation game: for any $y$ and any government's strategy in the first period, citizens play $s_{2} \mid 1=$ not overthrow, $s_{2} \mid 0=$ overthrow in the second period. Equilibrium strategies of the government in the second period are computed conditional on $\gamma$. In the parameter region in which the solution of a continuation game is given by (1)-(3) of Lemma 1, the continuation payoffs of the government after the first period depend on its type and the value of $\gamma$.

In particular, continuation payoffs, denoted by $V_{H}$ and $V_{L}$, are the following:

$$
\begin{gathered}
V_{H}=\left\{\begin{array}{c}
B+R+\delta\left(p_{H}+\left(1-p_{H}\right)(1-\gamma)\right)[B+R] \text { if } R>\gamma \delta\left(1-p_{H}\right)(B+R) \\
B+\delta[B+R] \text { if } \gamma \delta p_{L}(B+R)<R<\gamma \delta\left(1-p_{H}\right)(B+R) \\
B+\delta[B+R] \text { if } R<\gamma \delta p_{L}(B+R)
\end{array}\right. \\
V_{L}=\left\{\begin{array}{c}
B\left(1-p_{H}\right)(B+R) \\
B+R+\delta(1-\gamma)[B+R] \text { if } R>\gamma \delta(1-R) \text { if } \gamma \delta p_{L}(B+R)<R<\gamma \delta\left(1-p_{H}\right)(B+R)
\end{array}\right. \\
B+\delta(1-\gamma)\left[B+R\left(p_{L}+\left(1-p_{L}\right)(1-\gamma)\right)[B+R] \text { if } R<\gamma \delta p_{L}(B+R)\right.
\end{gathered}
$$

We are looking for Perfect Bayesian equilibrium. To find all pure strategy equilibrium, the strategy of each type of the government should be a best response to the strategy of the other type of government given beliefs. If the costs of overthrowing the government are small enough then the citizens will play $s_{1} \mid 1=$ not overthrow, $s_{1} \mid 0=$ overthrow. It is optimal for the people to overthrow the current government if $\gamma \delta\left(\widehat{\mu_{1}}-\mu\right)\left(\left.U^{2}\right|_{\theta=\theta_{H}}-\left.U^{2}\right|_{\theta=\theta_{L}}\right)<$ $-c(\gamma)$, where $\left.U^{2}\right|_{\theta=\theta_{i}}$ is the expected payoff of the citizens in the subsequent periods if the government's type in the beginning of the second period is $\theta_{i}$ (these expected payoffs depend on $\gamma$, because for different values of $\gamma$ governments play different strategies in the second period). As a competent government in the second period cannot predate when an incompetent one does not, $\left.U^{2}\right|_{\theta=\theta_{H}}-\left.U^{2}\right|_{\theta=\theta_{L}}>0$ for any $\gamma$. Therefore, if $c(\gamma)$ is sufficiently small then for all strategy profiles except $x_{H 1}=1, x_{L 1}=0, s_{1} \mid 1=$ not overthrow, $s_{1} \mid 0=$ overthrow is a best response 
as a positive outcome increases the ex-post probability of a high-competent government, while a negative outcome

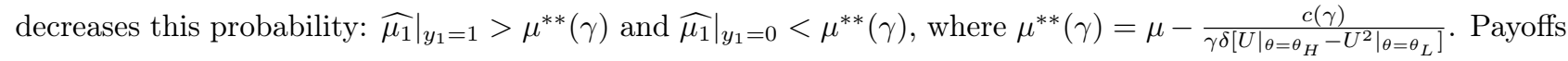
of the government are the following:

$$
\begin{aligned}
& U_{H}\left(x_{H 1}=1, x_{L 1}=1\right)=B+R+\delta\left(p_{H}+\left(1-p_{H}\right)(1-\gamma)\right) V_{H} \\
& U_{L}\left(x_{H 1}=1, x_{L 1}=1\right)=B+R+\delta(1-\gamma) V_{L} \\
& U_{H}\left(x_{H 1}=1, x_{L 1}=0\right)=B+R+\delta\left(p_{H}+\left(1-p_{H}\right)(1-\gamma)\right) V_{H} \\
& U_{L}\left(x_{H 1}=1, x_{L 1}=0\right)=B+\delta\left(p_{L}+\left(1-p_{L}\right)(1-\gamma)\right) V_{L} \\
& U_{H}\left(x_{H 1}=0, x_{L 1}=1\right)=B+\delta V_{H} \\
& U_{L}\left(x_{H 1}=0, x_{L 1}=1\right)=B+R+\delta(1-\gamma) V_{L} \\
& U_{H}\left(x_{H 1}=0, x_{L 1}=0\right)=B+\delta V_{H} \\
& U_{L}\left(x_{H 1}=0, x_{L 1}=0\right)=B+\delta\left(p_{L}+\left(1-p_{L}\right)(1-\gamma)\right) V_{L}
\end{aligned}
$$

Note that for both types of the government either $x_{i 1}=1$ or $x_{i 1}=0$ is a dominant strategy, i.e. if $x_{i 1}=1$ is a best response to $x_{-i, 1}=0$, it is also a best response to $x_{-i, 1}=1$. So, in order to find a Perfect Bayesian equilibrium, we just need to find out the conditions for dominance of $x_{i 1}=1$ for both $i \in\{H, L\}$.

The optimal strategy of a competent government is $x_{H 1}=1$ if

$$
B+R+\delta\left(1+p_{H} \gamma-\gamma\right) V_{H}>B+\delta V_{H}
$$

i.e. if $R>\delta\left(1-p_{H}\right) \gamma V_{H}$. For $R>\gamma \delta\left(1-p_{H}\right)(B+R)$, this condition can be rewritten as $R>\delta\left(1-p_{H}\right) \gamma(B+$ $R)\left(1+\delta+\delta p_{H} \gamma-\delta \gamma\right)$ and it is equivalent to

$$
\gamma^{2} \delta^{2}\left(1-p_{H}\right)^{2}-\gamma \delta\left(1-p_{H}\right)(1+\delta)+\frac{R}{B+R}>0
$$

We consider two cases: $R$ is small and $R$ is large. If $R$ is large, and, in particular, $(1+\delta)^{2}-\frac{4 R}{B+R}<0$, then the discriminant in (4) is negative, and for any $\gamma$ such that $\gamma<\frac{R}{\delta\left(1-p_{H}\right)(B+R)}$ the condition (4) is satisfied, and, therefore, $x_{H 1}=1$ is a dominant strategy. If $R$ is small, and, in particular, $\frac{R}{B+R}<\delta$, this implies that for $\gamma=\frac{R}{\delta\left(1-p_{H}\right)(B+R)}$, the left-hand side of (4) is equal to $\frac{R^{2}}{(B+R)^{2}}-\frac{R(1+\delta)}{B+R}+\frac{R}{B+R}=\frac{R^{2}-\delta R(B+R)}{(B+R)^{2}}<0$. The derivative of the left-hand side of (4) at this point is $\frac{2 R \delta\left(1-p_{H}\right)}{(B+R)}-\delta\left(1-p_{H}\right)(1+\delta)$ which is less than 0 , as $\frac{R}{B+R}<\delta$ implies $\frac{2 R}{B+R}<1+\delta$. This implies that the intersection of $\gamma<\frac{R}{\delta\left(1-p_{H}\right)(B+R)}$ and $(4)$ is $\left[0, \gamma_{1}\right]$ where $\gamma_{1}$ is a smaller solution of $\gamma^{2} \delta^{2}\left(1-p_{H}\right)^{2}-\gamma \delta\left(1-p_{H}\right)(1+\delta)+\frac{R}{B+R}=0$.

Now, consider the case $\gamma>\frac{R}{\delta\left(1-p_{H}\right)(B+R)}$. The optimal strategy of a competent government is $x_{H 1}=1$ if $R>\delta\left(1-p_{H}\right) \gamma(B+\delta(B+R))$, or, equivalently, if $\gamma<\frac{R}{\delta\left(1-p_{H}\right)(B+\delta(B+R))}$. If $R$ is large, and $R>\delta(B+R)$, this 
implies that $\frac{R}{\delta\left(1-p_{H}\right)(B+\delta(B+R))}>\frac{R}{\delta\left(1-p_{H}\right)(B+R)}$, and $x_{H 1}=1$ is optimal for $\gamma<\frac{R}{\delta\left(1-p_{H}\right)(B+\delta(B+R))}$. As a result, if $R$ is large, $x_{H 1}=1$ is optimal if $\gamma<\frac{R}{\delta\left(1-p_{H}\right)(B+\delta(B+R))}$, i.e. if $\gamma$ is sufficiently small. If $R$ is small, this implies that $\gamma<\frac{R}{\delta\left(1-p_{H}\right)(B+\delta(B+R))}$ and $\gamma>\frac{R}{\delta\left(1-p_{H}\right)(B+R)}$ is not a compatible system of inequalities. Overall, if $R$ is small, $x_{H 1}=1$ is optimal if $\gamma<\gamma_{1}$.

The optimal strategy of an incompetent government is $x_{L 1}=1$ if

$$
B+R+\delta(1-\gamma) V_{L}>B+\delta\left(p_{L}+\left(1-p_{L}\right)(1-\gamma)\right) V_{L}
$$

i.e. if $R>\delta p_{L} \gamma V_{L}$. For $R>\gamma \delta p_{L}(B+R)$, this condition can be rewritten as $R>\delta p_{L} \gamma(B+R+\delta(1-\gamma)[B+R])$ which is equivalent to

$$
\gamma^{2} \delta^{2} p_{L}-\gamma \delta p_{L}(1+\delta)+\frac{R}{B+R}>0
$$

As before, we consider two cases: $R$ is small and $R$ is large. If $R$ is large, and, in particular, $(1+\delta)^{2}-\frac{4 R}{p_{L}(B+R)}<0$, the proof is similar to the previous case. For any $\gamma$ such that $\gamma<\frac{R}{\delta p_{L}(B+R)}$, condition (5) is satisfied, and, therefore, $x_{L 1}=1$ is a dominant strategy. If $R$ is small, and, in particular, $\frac{R}{B+R}<\delta p_{L}$, this implies that for $\gamma=\frac{R}{\delta p_{L}(B+R)}$, the left-hand side of (5) is equal to $\frac{R^{2}}{p_{L}(B+R)^{2}}-\frac{R(1+\delta)}{B+R}+\frac{R}{B+R}=\frac{R^{2}-\delta p_{L} R(B+R)}{(B+R)^{2}}<0$. This implies that the intersection of $\gamma<\frac{R}{\delta p_{L}(B+R)}$ and $(5)$ is $\left[0, \gamma_{2}\right]$ where $\gamma_{2}$ is a smaller solution of $\gamma^{2} \delta^{2} p_{L}-\gamma \delta p_{L}(1+\delta)+\frac{R}{B+R}=0$.

Now, consider the case $\gamma>\frac{R}{\delta p_{L}(B+R)}$. The optimal strategy of an incompetent government is $x_{L 1}=1$ if $R>\delta p_{L} \gamma\left(B+\delta\left(p_{L}+\left(1-p_{L}\right)(1-\gamma)\right)[B+R]\right)$, or, equivalently, if

$$
\gamma^{2} \delta^{2} p_{L}\left(1-p_{L}\right)(B+R)-\gamma \delta p_{L}(B+\delta(B+R))+R>0
$$

If $R$ is large, this implies that the discriminant $\delta^{2}\left[p_{L}^{2}(B+\delta(B+R))^{2}-4 R p_{L}\left(1-p_{L}\right)(B+R)\right]$ is less than 0 (if $p_{L}<\frac{4}{4+\delta^{2}}$ ), and, consequently, (6) is always satisfied. If, in contrast, $R$ is small, and, in particular, $R<$ $\min \left\{\frac{\delta p_{L} B}{1-p_{L} \delta}, \frac{\delta p_{L}\left(1+\delta p_{L}\right) B}{1-p_{L}^{2} \delta^{2}}\right\}$, then the left-hand side of (6) is negative for both $\gamma=\frac{R}{\delta p_{L}(B+R)}$ and $\gamma=1$. As a result, if $R$ is small, there is no $\gamma$ such that (6) is satisfied and $\gamma>\frac{R}{\delta p_{L}(B+R)}$. Overall, if $R$ is large, $x_{L 1}=1$ is always optimal. If $R$ is small, $x_{L 1}=1$ is optimal if $\gamma<\gamma_{2}$.

As a result, possible equilibria in the first stage are the following. If $R$ is large, the equilibrium set of strategies is $x_{L 1}=1, x_{H 1}=1, s_{1} \mid 1=$ not overthrow, $s_{1} \mid 0=$ overthrow if $\gamma$ is relatively small (i.e. $\gamma<\frac{R}{\delta\left(1-p_{H}\right)(B+\delta(B+R))}$ ); $x_{L 1}=1, x_{H 1}=0, s_{1} \mid 1=$ not overthrow, $s_{1} \mid 0=$ overthrow if $\gamma$ is relatively large $\left(\right.$ i.e. $\left.\gamma>\frac{R}{\delta\left(1-p_{H}\right)(B+\delta(B+R))}\right)$. If $R$ is small, the equilibrium set of strategies is $x_{L 1}=1, x_{H 1}=1, s_{1} \mid 1=$ not overthrow, $s_{1} \mid 0=$ overthrow if $\gamma$ is sufficiently small (i.e. $\gamma<\gamma_{1}$ ), $x_{L 1}=1, x_{H 1}=0, s_{1} \mid 1=$ not overthrow, $s_{1} \mid 0=$ overthrow if $\gamma$ is in intermediate 
range $\left(\gamma \in\left[\gamma_{1}, \gamma_{2}\right]\right)$, and $x_{L 1}=0, x_{H 1}=0, s_{1} \mid 1=$ not overthrow, $s_{1} \mid 0=$ overthrow if $\gamma$ is sufficiently large (i.e. $\left.\gamma>\gamma_{2}\right)$.

Equilibria in continuation games are described above in lemma 1.

Proof. [Proposition 2] From the proof of lemma 1, $\left.\widehat{\mu_{1}}\right|_{y_{1}=0, x_{H 1}=1, x_{L 1}=1}=\frac{\mu *\left(1-p_{H}\right)}{1-\mu p_{H}}<\mu,\left.\widehat{\mu_{1}}\right|_{y_{1}=0, x_{H 1}=0, x_{L 1}=1}=0<$ $\mu$, and $\left.\widehat{\mu_{1}}\right|_{y_{1}=0, x_{H 1}=0, x_{L 1}=0}=0<\mu$. In any case, the risk of predation goes up, as a low-competent government predate more often.

Proof. [Proposition 3] We can compute the risk of predation in the second period as $\operatorname{Prob}($ predation $\mid \mu=0) *$ $\operatorname{Prob}(\mu=0)+\operatorname{Prob}($ predation $\mid \mu=1) * \operatorname{Prob}(\mu=1)$. The estimated risk of predation (the risk of predation, estimated by people) is $\operatorname{Prob}($ predation $\mid \mu=0) * \operatorname{Prob}(\mu=0)+\operatorname{Prob}($ predation $\mid \mu=1) * \operatorname{Prob}(\mu=1)$. If $\gamma$ is large or $\gamma$ is small, $\operatorname{Prob}($ predation $\mid \mu=0)=\operatorname{Prob}($ predation $\mid \mu=1)$, and the change in the risk of predation is generated by the change in $\operatorname{Prob}(\mu=1)$ and, correspondingly, $\operatorname{Prob(\mu }=0)$. In the intermediate range of $\gamma, \operatorname{Prob}(\operatorname{predation} \mid \mu=$ 1) $<\operatorname{Prob}($ predation $\mid \mu=0)$, so the change in the risk of predation is higher even if $\mu-\operatorname{Prob(\mu }=1)$ remains the same.

Now what we need is to compare $\mu-\operatorname{Prob(\mu =1)}$ in all three types of regimes, i.e., as the proof of lemma 1 suggests, to compare $\mu-\frac{\mu *\left(1-p_{H}\right)}{1-\mu p_{H}}, \mu$, and $\mu$. So, in addition to $\operatorname{Prob}($ predation $\mid \mu=1)<\operatorname{Prob}($ predation $\mid \mu=0)$, the increase in the estimated risk of predation is the not smaller in the intermediate regimes as compared with other regimes. ${ }^{12}$

\footnotetext{
${ }^{12}$ Note that if we assume that some governments are impatient with some small probability, i.e. they do not care about the future periods, then this increase is strictly larger in intermediate regimes than in other types of regimes. We do not use this assumption in the present version of the paper to save space.
} 